Article

\title{
Daylighting Performance of Light Shelf Photovoltaics (LSPV) for Office Buildings in Hot Desert-Like Regions
}

\author{
Abdelhakim Mesloub ${ }^{1, *(1)}$ and Aritra Ghosh $2, *$ (D) \\ 1 Department of Architectural Engineering, Ha'il University, Ha'il 2440, Saudi Arabia \\ 2 College of Engineering, Mathematics and Physical Sciences, Renewable Energy, University of Exeter, Penryn, \\ Cornwall TR10 9FE, UK \\ * Correspondence: a.maslub@uoh.edu.sa (A.M.); a.ghosh@exeter.ac.uk (A.G.)
}

Received: 19 October 2020; Accepted: 5 November 2020; Published: 10 November 2020

\begin{abstract}
Visual comfort and energy consumption for lighting in large office buildings is an area of ongoing research, specifically focusing on the development of a daylight control technique (light shelf) combined with solar energy. This study aims to investigate the optimum performance of light shelf photovoltaics (LSPV) to improve daylight distribution and maximize energy savings for the hot desert-like climate of Saudi Arabia. A radiance simulation analysis was conducted in four phases to evaluate: appropriate height, reflector, internal curved light shelf (LS) angle, and the integrated photovoltaic (PV) with various coverages $(25 \%, 50 \%, 75 \%$, and entirely external LS). The results revealed that the optimum is achieved at a height of $1.3 \mathrm{~m}$, the addition of a $30 \mathrm{~cm}$ reflector on the top of a window with an internal LS curved angle of $10^{\circ}$ with $100 \%$ coverage (LSPV1, LSPV2). Such an arrangement reduces the energy consumption by more than $85 \%$, eliminates uncomfortable glare, and provides uniform daylight except for during the winter season. Hence, the optimization of the LSPV system is considered to be an effective solution for sustainable buildings.
\end{abstract}

Keywords: LSPV; visual comfort; energy consumption; angle

\section{Introduction}

Presently, the Kingdom of Saudi Arabia is witnessing unprecedented development as part of the implementation of its ambitious 2030 vision. Launched in 2016, the vision intends to build a thriving, diversified, and sustainable economic model which has a lesser dependence on the income from oil and savings from fossil fuel subsidies [1]. Solar energy has been recognized as a relatively significant source of renewable energy compared to the other sustainable energy sources in the Kingdom of Saudi Arabia. Considering the ample solar radiance and the prevailing desert-like climatic conditions [2], photovoltaic (PV) technology could play a vital role in overcoming energy issues in this hot and arid region [3]. The Saudi Electricity Company revealed that lighting accounts for over $30 \%$ of the total energy consumed in office buildings to provide the required amount of light [4]. Therefore, the rationalization of energy use and the improvement of daylighting design techniques such as light shelves [5-7], semi-transparent photovoltaics (STPV) [8], louvers [9], and light transportation [10] need to be considered.

One of the essential daylighting techniques is light shelves. A light shelf is a horizontal surface that reflects daylight deep inside a building. Light shelves are placed above eye-level and have highly reflective upper surfaces that reflect daylight onto the ceiling and deeper into a space. It is a flexible system that offers a variety of design solutions. It can be installed easily on an external or internal surface [6], and can be designed in various geometries like fixed flat models and curved reflective surfaces [11], dynamic shading device design [5,12], and integrated as a solar module [13]. Thus, precise operation of the various design solutions associated with light shelves, such as solar 
modules, is required to enhance lighting and electricity generation efficiency in response to external conditions, as depicted in Figure 1.

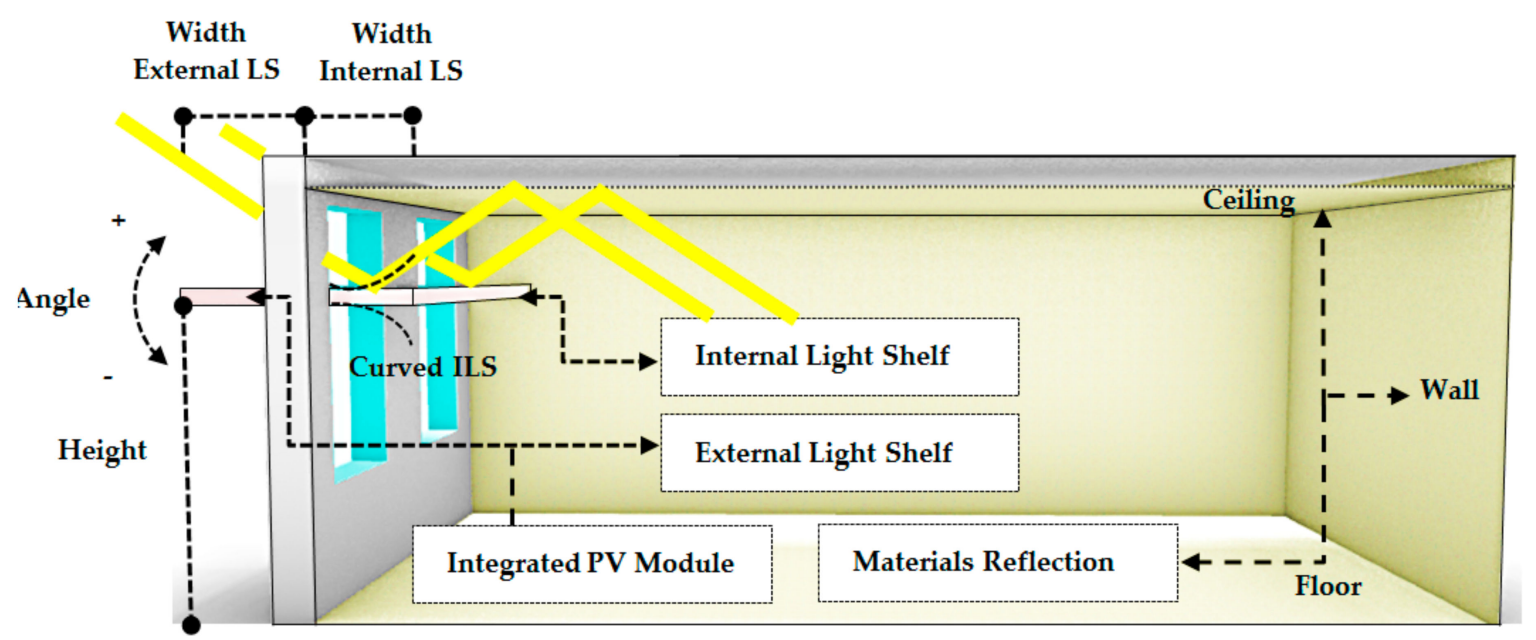

Figure 1. Design solutions and variables associated with a light shelf that influence the daylight distribution.

Much research has been conducted concerning the daylight performance of light shelves using several configurations (dimensions, geometry, angles, and material) using experiments in the field under varying sky conditions or through simulations. As specified in Table 1, previous research has primarily evaluated the optimization of the aspects concerning light shelves to enhance the distribution of daylight in vast spaces to facilitate enhanced visual comfort. Nevertheless, there was specific research concerning a light shelf whose width and length was modified by isolating the light shelf reflector along with the bottom and top reflectors [14].

Several other studies analyzed an integration of building envelope technologies like louvres [15], in-built photovoltaics (PV) [13], and awning systems [16] to facilitate a decrease in the energy requirements of the building. A review of the existing literature indicates that there are only a few pieces of research that assess the performance of solar panels integrated with light shelves. Hwang et al. [17] examined the characteristics of the light shelf system using in-built PVs by lining the outer light shelf with solar panels in a southern orientation, placed at varying angles. Heangwoo Lee [13] recently suggested a solar-integrated light shelf having only a fraction of it covered with solar panels at varying angles; however, the internal shelf would not be used. Hence, the current study aims to assess the optimum performance of the combination of external and internal light shelves using integrated solar panels in several places to facilitate the appropriate distribution of daylight in the office structure and optimize energy savings, especially under the hot desert-like climatic conditions of Ha'il city.

Table 1. Studies conducted on light shelf performance on daylighting.

\begin{tabular}{|c|c|c|c|c|}
\hline Title of Study and Year & $\begin{array}{l}\text { Light Shelf } \\
\text { Parameters }\end{array}$ & $\begin{array}{l}\text { Experimental } \\
\text { Measurement }\end{array}$ & $\begin{array}{l}\text { Daylighting } \\
\text { Simulation }\end{array}$ & $\begin{array}{c}\text { Integrated PV } \\
\text { with Light Shelf }\end{array}$ \\
\hline $\begin{array}{l}\text { Maximizing the light shelf } \\
\text { performance by interaction between } \\
\text { light shelf geometries and a curved } \\
\text { ceiling, Jordan, } 2010 \text { [11] }\end{array}$ & $\begin{array}{l}\text { Geometries, curved } \\
\text { ceiling }\end{array}$ & no & yes & no \\
\hline $\begin{array}{l}\text { Power performance of } \\
\text { photovoltaic-integrated lightshelf } \\
\text { systems, South Korea, 2014, [17] }\end{array}$ & $\begin{array}{l}\text { Full solar panel } \\
\text { (one size) }\end{array}$ & yes & yes & yes \\
\hline $\begin{array}{l}\text { Analysis of the Impacts of Light } \\
\text { Shelves on the Useful Daylight } \\
\text { Illuminance in Office Buildings in } \\
\text { Toronto, 2015, [18] }\end{array}$ & $\begin{array}{l}\text { Width, depth, and } \\
\text { height }\end{array}$ & no & yes & no \\
\hline
\end{tabular}


Table 1. Cont.

\begin{tabular}{|c|c|c|c|c|}
\hline Title of Study and Year & $\begin{array}{l}\text { Light Shelf } \\
\text { Parameters }\end{array}$ & $\begin{array}{l}\text { Experimental } \\
\text { Measurement }\end{array}$ & $\begin{array}{l}\text { Daylighting } \\
\text { Simulation }\end{array}$ & $\begin{array}{c}\text { Integrated PV } \\
\text { with Light Shelf }\end{array}$ \\
\hline $\begin{array}{l}\text { Dynamic internal light shelf for } \\
\text { tropical daylighting in high-rise office } \\
\text { buildings, Malaysia, 2016, [5] }\end{array}$ & $\begin{array}{l}\text { Height of ILS, } \\
\text { number of ILS }\end{array}$ & yes & yes & no \\
\hline $\begin{array}{l}\text { Evaluating daylight performance of } \\
\text { light shelves combined with external } \\
\text { blinds in south-facing classrooms in } \\
\text { Athens, 2016, [15] }\end{array}$ & $\begin{array}{l}\text { Material, angle, } \\
\text { combination with } \\
\text { louvers }\end{array}$ & no & yes & no \\
\hline $\begin{array}{l}\text { Investigating the Influence of Light } \\
\text { Shelf Geometry Parameters on } \\
\text { Daylight Performance and Visual } \\
\text { Comfort, a Case Study of Educational } \\
\text { Space in Tehran, Iran, 2016, [19] }\end{array}$ & $\begin{array}{c}\text { Dimension, angle, } \\
\text { orientation }\end{array}$ & no & yes & no \\
\hline $\begin{array}{l}\text { Energy-saving performance of light } \\
\text { shelves under the application of } \\
\text { user-awareness technology and } \\
\text { light-dimming control, South Korea, } \\
2018,[20] \text {. }\end{array}$ & Angle & yes & yes & no \\
\hline $\begin{array}{l}\text { A preliminary study on the } \\
\text { performance of an awning system } \\
\text { with a built-in light shelf, South } \\
\text { Korea, 2018, [16]. }\end{array}$ & $\begin{array}{l}\text { Angle, awning } \\
\text { system }\end{array}$ & yes & yes & no \\
\hline $\begin{array}{l}\text { Development and Performance } \\
\text { Evaluation of Light Shelves Using } \\
\text { Width-Adjustable Reflectors, South } \\
\text { Korea, 2018, [21]. }\end{array}$ & Width adjustability & yes & no & no \\
\hline $\begin{array}{l}\text { Performance evaluation of a light } \\
\text { shelf with a solar module based on } \\
\text { the solar module attachment area, } \\
\text { South Korea, 2019, [13]. }\end{array}$ & Angle, PV coverage & yes & yes & yes \\
\hline $\begin{array}{l}\text { Experimental Analysis of the } \\
\text { Performance of Light Shelves in } \\
\text { Different Geometrical Configurations } \\
\text { Through the Scale Model Approach, } \\
\text { South Korea, 2020, [6]. }\end{array}$ & $\begin{array}{l}\text { Angle, curved LS, } \\
\text { ILS reflector }\end{array}$ & yes & no & no \\
\hline $\begin{array}{l}\text { Optimization of Daylight } \\
\text { Performance Based on Controllable } \\
\text { Light-shelf Parameters using Genetic } \\
\text { Algorithms in the Tropical Climate of } \\
\text { Malaysia, 2020, [22] }\end{array}$ & $\begin{array}{l}\text { Angle, width/depth } \\
\text { ratio, height, and } \\
\text { reflectivity }\end{array}$ & yes & yes & no \\
\hline $\begin{array}{l}\text { Performance Evaluation of External } \\
\text { Light Shelves by Applying a Prism } \\
\text { Sheet, South Korea, 2020, [23]. }\end{array}$ & $\begin{array}{l}\text { Applying prism } \\
\text { sheets with angles }\end{array}$ & yes & no & no \\
\hline
\end{tabular}

\subsection{The Sun Path of Ha'il City}

Sun path diagrams are appropriate for depicting the annual changes happening about the Sun's path. As shown in Figure 2, the midday sun in Ha'il city is at a $39^{\circ}$ inclination during the winter solstice. The inclination is $84^{\circ}$ during the summer solstice. These numbers indicate a $45^{\circ}$ deviation between the solstices as a result of the Earth's declination, varying between $-23^{\circ}$ and $+23^{\circ}$ over the year. In contrast, during spring and autumn, the Sun has a similar path and an inclination of $63^{\circ}$, which is present between the two solstices. 


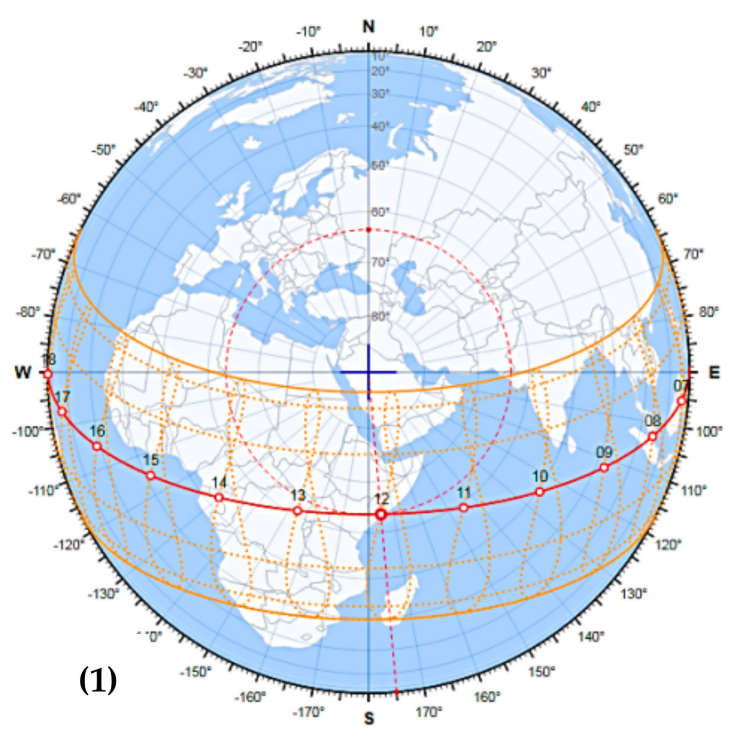

$39.00^{\circ}$

(a)

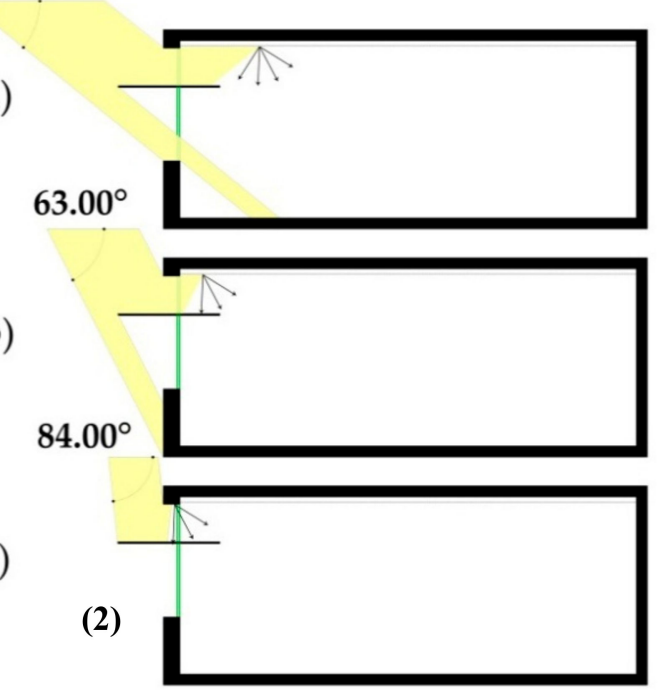

Figure 2. (1) Sun path at the city of Ha'il using Andrew-Marsh 2D modeling, (2) the inflow of daylight corresponding to the incident angle of design rays at midday. (a) Winter solstice; (b) spring/autumn equinox; (c) summer solstice.

The solar energy incident on the southern and northern parts of the building is not the same since the southern side has better incident sunlight compared to the northern side. In contrast, considering the eastern and western directions, the incident solar energy exhibits symmetry. As a result, there should be a difference in the light intensity once the light shelves are attached.

\subsection{Recommended Indoor Illuminance}

According to the International Organization for Standardization (ISO) standard 8995-1:2002 [24], typically, the illumination at the workplace (especially in areas comprising continuous work) should not fall below 300 lux; however, the delta between the suggested illuminances is not substantial because they are usually associated with the Commission International d'Eclairage (CIE) regulations. Recommended illumination in the United States [25], Japan [26], and European countries [27] range between 300 lux to 1000 lux. For most countries whose data were reviewed, 500 lux illumination is maintained at the desk level for routine office work, as presented in Appendix A. Most countries recommend 750 lux for drawing since it is a task that requires high accuracy. In contrast, the lower limit of horizontal illumination in an office setting concerning a computer lies in the 300-750 lux range. In this study, the indoor illumination standard for light shelf performance evaluation was set to between 300-750 lux based on the review of the aforementioned optimum indoor illumination standards.

\section{Materials and Methods}

This research considers both qualitative and quantitative analyses of the simulation of numerical parameters (reflector, height, and Internal light shelf (ILS) curve) as a mechanism for three-phased data collection. Subsequently, the PV modules are integrated at varying coverage values.

The following sections present the simulation technique, the light shelf configurations used for the case study, and the assessment criteria implemented in this study. Figure 3 provides a summary of the chosen case. 


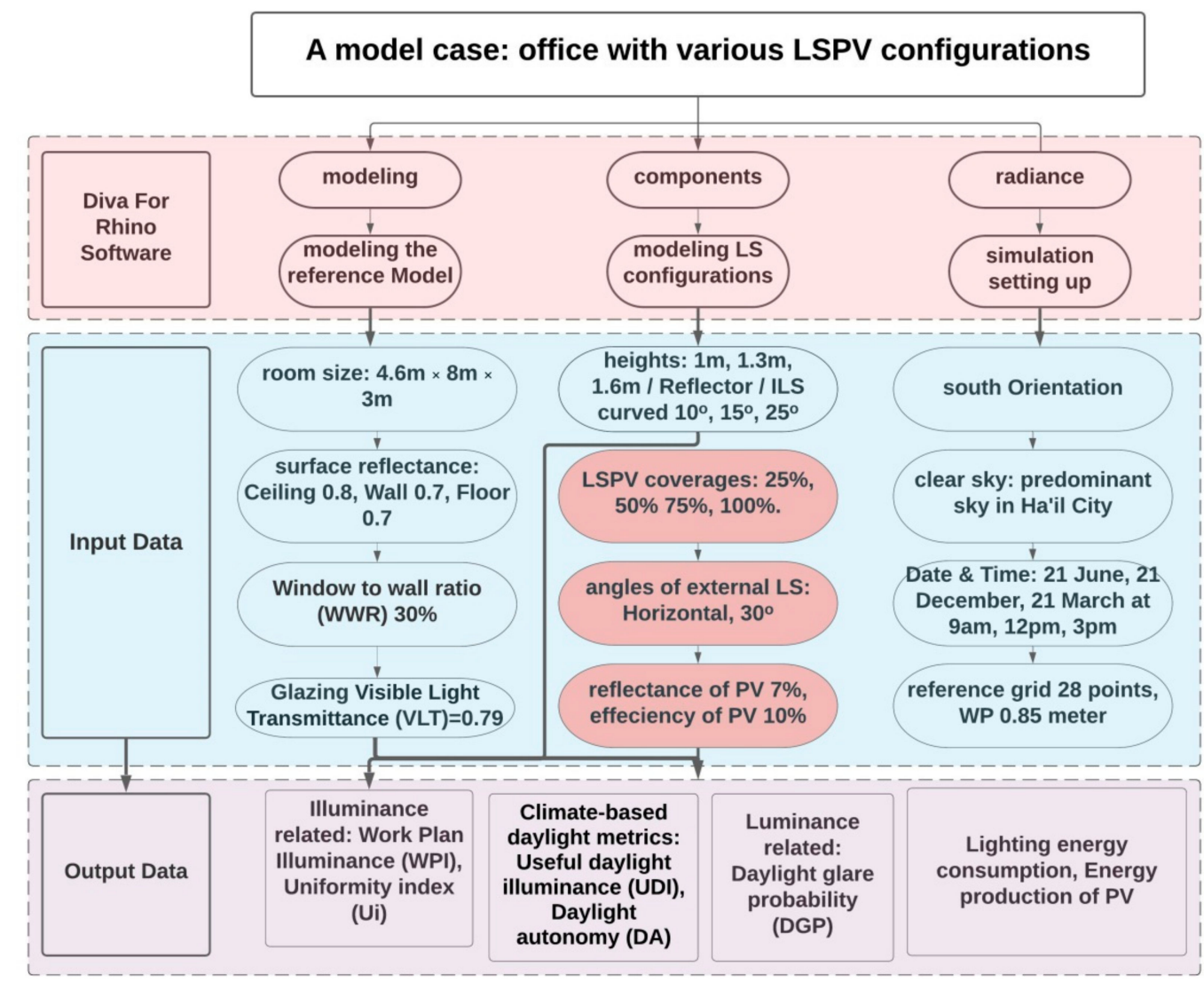

Figure 3. Schematic diagram for the simulation method.

\subsection{Computer Simulation (Diva for Rhino)}

This research used Diva for Rhino as the tool to simulate daylight performance for different light shelf configurations. Diva employs a Radiance backwards ray-tracer calculation method and the DAYSIM daylighting analysis engine to run daylight simulation [28]. The software considers the distribution of emitted rays and supports the analysis of reflection, transmission and refraction from surfaces. The Meteonorm metrological database (TMY) is used by Diva, where the hourly data of weather aspects like radiance, illuminance, temperature and humidity are validated by the rating authority [29].

\subsection{Light Shelf Configurations}

In this study, 11 internal-external light shelf configurations were tested using daylight simulation, as shown in Table 2. The combined internal and external light shelf (LS) configurations have been assessed using four main phases: 
Table 2. Light shelf configurations used in simulation for each phase.

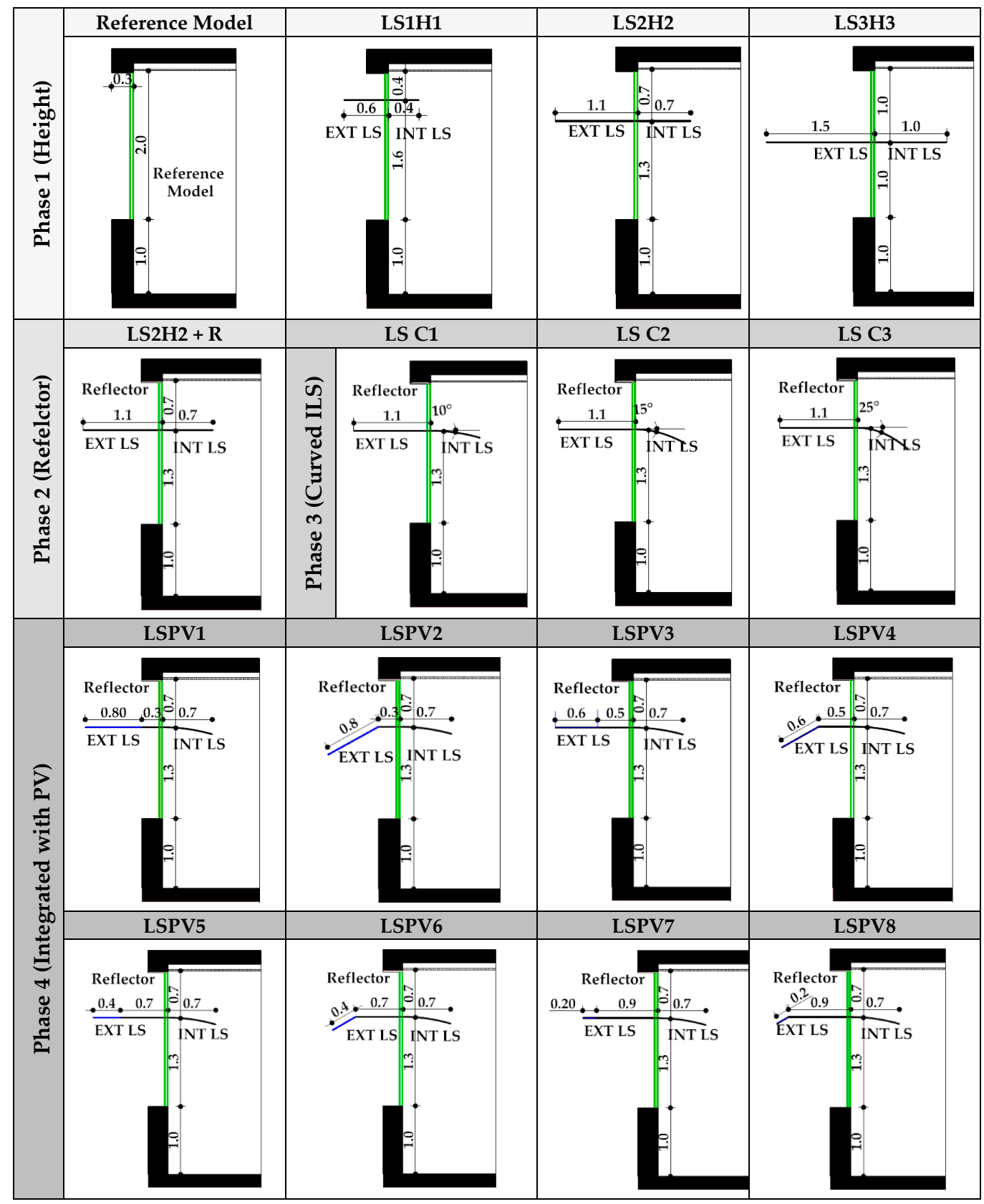

- First phase: three horizontal light shelves of different dimensions, placed at varying heights as defined by previous studies [30-32]. The Internal LS depth is equal to the height of the clerestory window above it while the external LS depth is 1.5 times the height of the clerestory window.

$$
\begin{gathered}
\mathrm{d}_{\text {int light shelf }}=\mathrm{h}_{\text {clerestory }} \\
\mathrm{d}_{\text {extlight shelf, max }} \leq 1.5 \times \mathrm{h}_{\text {clerestory }}
\end{gathered}
$$

The three configurations in the first phase are LS1H1, LS2H2, and LS3H3, and they have fixed heights of $1.6 \mathrm{~m}, 1.3 \mathrm{~m}$, and $1.0 \mathrm{~m}$, respectively. 
- Second Phase: once the appropriate height of the LS is chosen, a reflector material is added on the top of the window to enhance the illumination of the daylit area at the back and then compared with the reference model.

- Third phase: three downward-curved internal LS (having angles of $10^{\circ}, 15^{\circ}$ and $25^{\circ}$ ) were examined and compared with horizontal internal LSs with the reflector material specified in the second phase.

- Fourth Phase: four different PV coverage and tilt angles are integrated with the external LS. LSPV1, LSPV3, LSPV5, and LSPV7 are designed to have external horizontal light shelves with $100 \%, 75 \%, 50 \%$, and $25 \%$ coverage, respectively. The remaining configurations of LSPVs have the same coverage but are tilted at $30^{\circ}$ to reflect maximum energy and prevent the occurrence of glare.

\subsection{Description of the Case Study and Climatic Conditions}

The model chosen for reference in this case study considers a typical vast office structure built in 'Diva for Rhino' with a depth of $8.0 \mathrm{~m}$ and a width of $4.6 \mathrm{~m}$. As depicted in Figure 4, the office was aligned with the southern façade using a lateral typology. In the context of the reference model, the window-to-wall ratio (WWR) is 0.3. At the same time, the opening is double glazed using low-E material, and has a visible light transmittance (VLT) value of 0.79 . Table 3 lists the radiance parameters used for daylighting simulation.
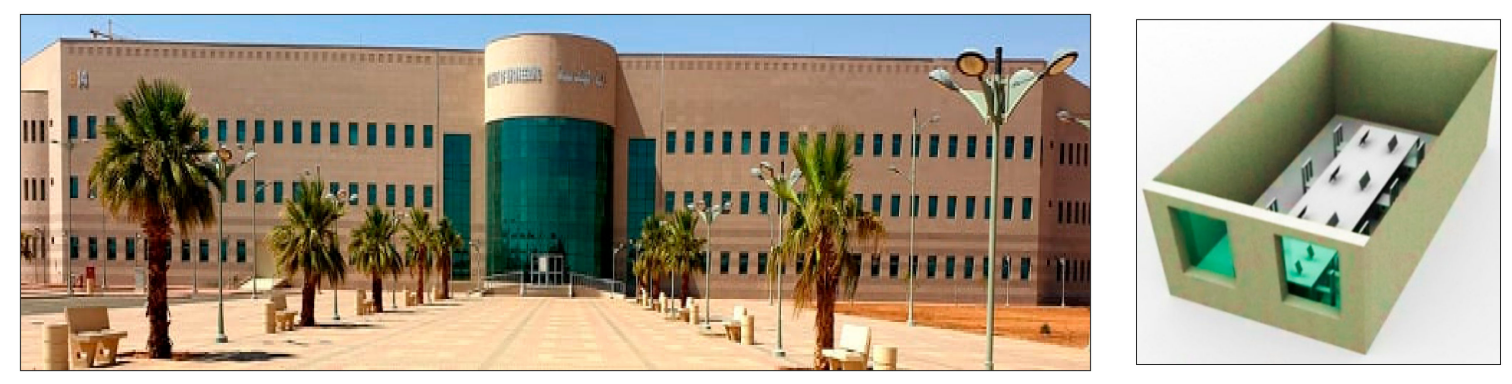

Figure 4. Exterior and interior 3D reference model and furniture arrangement.

Table 3. Radiance parameters used in the daylighting simulation.

\begin{tabular}{cccccc}
\hline Radiance Parameter & Ambient Bounces & Ambient Divisions & Ambient Sampling & Ambient Accuracy & Ambient Resolution \\
\hline Value & 7 & 1500 & 100 & 0.1 & 300 \\
\hline
\end{tabular}

This study used data pertaining to the Ha'il area as representative of the hot desert-like climate of Saudi Arabia, which is summarized in Table 4. This area is located around the center of the Arabian Peninsula, and its coordinates are $27^{\circ} 31^{\prime} \mathrm{N}, 41^{\circ} 41^{\prime} \mathrm{E}$. The average temperature is $31.1^{\circ} \mathrm{C}$ and the coldest month is January, which has a mean temperature of $10.6^{\circ} \mathrm{C}$. The area receives intense solar radiation - the average monthly incident solar energy experiences significant seasonal variation over the course of the year. The monthly maximum global horizontal radiation values range from $243 \mathrm{kWh} / \mathrm{m}^{2}$ in summer and $118 \mathrm{kWh} / \mathrm{m}^{2}$ in winter. At the same time, the global diffuse radiance is approximately $29 \%$. There is shallow cloud cover in this area. The area experiences clear skies on more than $70 \%$ of the days in an average year, while $29 \%$ of the days are overcast or mostly overcast; hence, this area has clear sky conditions according to the CIE standard [33]. Furthermore, the daylight range is between $10.4-13.6 \mathrm{~h}$, which indicates plenty of daylight through the year. 
Table 4. Monthly climatic conditions of Ha'il city.

\begin{tabular}{|c|c|c|c|c|c|c|c|c|c|c|c|c|}
\hline & January & February & March & April & May & June & July & August & September & October & November & December \\
\hline Average air temperature $\left({ }^{\circ} \mathrm{C}\right)$ & 10.2 & 13.5 & 17.8 & 23.3 & 28.1 & 31.9 & 33.2 & 33.8 & 30.6 & 25.1 & 17 & 12.2 \\
\hline Global horizontal irradiance $\left(\mathrm{kWh} / \mathrm{m}^{2}\right)$ & 125 & 132 & 183 & 204 & 228 & 243 & 238 & 225 & 195 & 168 & 125 & 118 \\
\hline Global diffuse irradiance $\left(\mathrm{kWh} / \mathrm{m}^{2}\right)$ & 38 & 40 & 53 & 62 & 64 & 56 & 61 & 60 & 51 & 45 & 40 & 29 \\
\hline Sun hours & 10.6 & 11.2 & 12 & 12.8 & 13.5 & 13.8 & 13.7 & 13.1 & 12.3 & 11.5 & 10.8 & 10.4 \\
\hline Cloud cover (\%) & 26 & 22 & 23 & 24 & 17 & 3 & 10 & 9 & 6 & 17 & 26 & 29 \\
\hline
\end{tabular}




\subsection{Modelling Approach and Analysis Criteria}

The simulated work plane illuminance (WPI) values were transcribed into a tabular form which contains the average illumination of four grid points in each row (lines as shown in Figure 5a). Furthermore, the quality of daylight distribution employed the uniformity index (Ui) of interior daylight, which is the ratio of the average illumination to the maximum illumination. This ratio should not be less than 0.6 above the work plane, as per the NBN L13-001 code and international guidelines [34]. The simulations were performed within the design days at the summer and winter solstices and during the mid-season (21 June, 21 December, 21 March) at 9.00 a.m., 12.00 p.m., and 3.00 p.m. to evaluate the annual variation and the critical period. The choice of the simulated points (grids) inside the office followed the grids plotted as per the arrangement of work planes. The minimum number of points in the deep-office prototype was 28 . The distance between the simulated grid points was kept at $1 \mathrm{~m}$ for accurate results, as depicted in Figure 5. The reflection by the surfaces used in this experimental set is presented in Table 5.
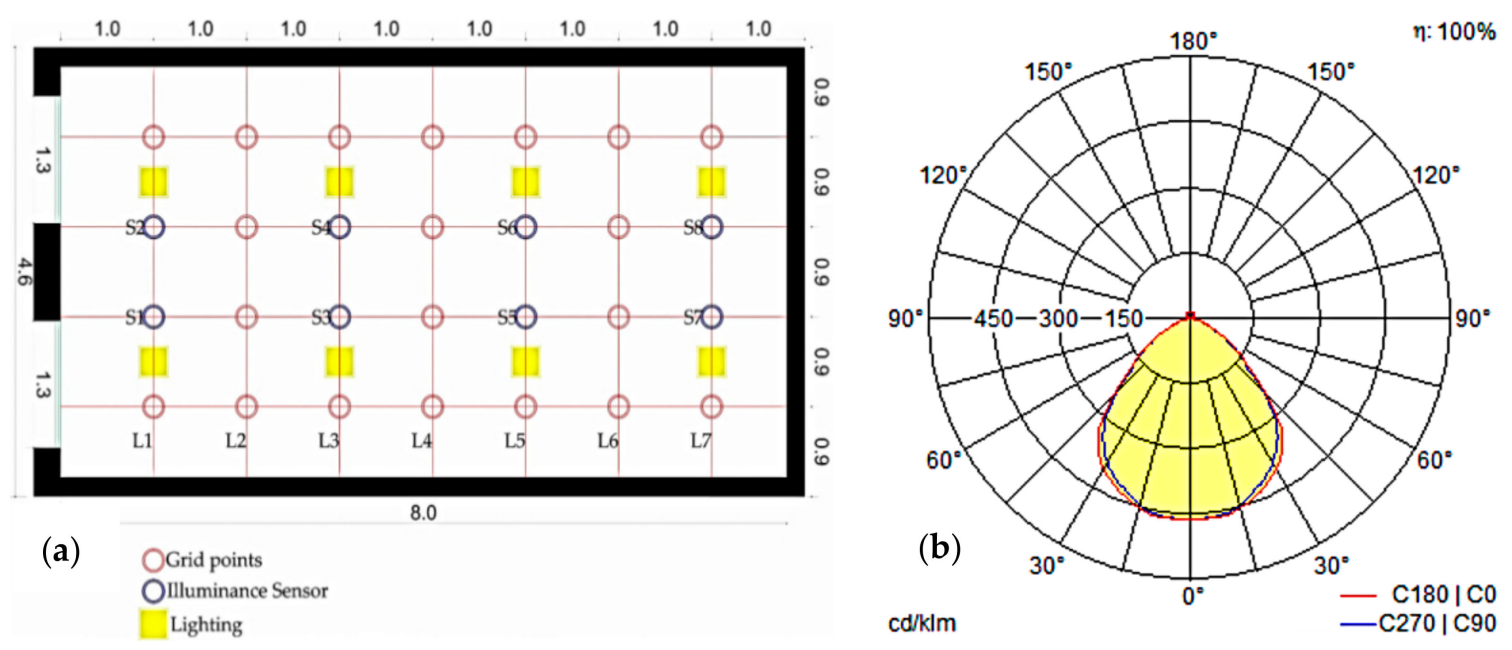

Figure 5. (a) Plan view representation of the grid points, illuminance sensors and lighting positions, (b) light distribution of conical illuminance.

Table 5. Material reflection coefficient percentages.

\begin{tabular}{cc}
\hline Material & Reflection Coefficient \\
\hline Ceiling & $80 \%$ \\
Floor & $20 \%$ \\
Wall & $70 \%$ \\
Furniture & $50 \%$ \\
Light shelf & $90 \%$ \\
Solar panel & $07 \%$ \\
Reflector & $99 \%$ \\
Double glazing low-E & VLT 79\% \\
\hline
\end{tabular}

For more details, the analysis of LSPV in last phase used climate-based daylight metrics that include the useful daylight illuminance (UDI), daylight autonomy (DA) and daylight glare probability (DGP), supported by a 3D illuminance contour map for glare assessments. The criteria of assessments of each metric are summarized in Table 6. The simulation of lighting energy consumption is through daylight control strategy (photosensor controlled dimming: 300 lux), where eight light-emitting diode (LED) indoor artificial lights (17.5 W luminaire power, luminaire luminous flux: $1552 \mathrm{~lm}$ and luminaire efficacy: $89 \mathrm{~lm} / \mathrm{W}$ ) were placed in the middle of line 1,3,5 and 7 and linked with illumination sensors (S1, S2, S3, S4, S5, S6, S7 and S8). The light distribution of the lighting in this study is shown in 
Figure $5 \mathrm{~b}$. The illumination sensors were placed $0.85 \mathrm{~m}$ above the floor surface, based on the height of the work plane. Their operating profiles follow their real use from 8.00 a.m. to 5.00 p.m.

Table 6. The performance indicators of visual comfort used in this study.

\begin{tabular}{ll}
\hline Criteria & Performance Indicator of Delighting Quantity and Quality \\
\hline WPI & WPI recommended 300-750 lux \\
\hline UI & Uniformity index must be greater than 0.5 \\
\hline \multirow{2}{*}{ UDI } & 100 lux $<$ dark area (need artificial light) \\
& 100 lux-2000 lux (comfortable), at least $50 \%$ of the time \\
& $>2000$ lux too bright with thermal discomfort \\
\hline DA & Set up 300 lx \\
\hline & $0.35<$ imperceptible glare \\
DGP & $0.35-0.40$ perceptible glare \\
& $0.4-0.45$ disturbing glare \\
\hline Net energy & Energy production of solar panels-energy consumption of artificial lighting \\
\hline
\end{tabular}

The amount of energy produced by the multi-crystalline photovoltaic module was derived using the Simple model. This model was simulated by multiplying the fraction of surface area that had active solar cells by the total solar radiation incident on the PV array; module conversion efficiency was set to $n=10 \%$. While the area of the solar module used varies according to the case set used in this study, the amount of energy produced depends primarily on photovoltaic array efficiency and inverter modelling efficiencies at the operating conditions. Nevertheless, the difference between lighting energy consumption and the energy produced is either positive or negative. Hence, for every configuration, the net energy production is the most significant performance indicator required to determine the optimum LSPV configuration.

\section{Results and Discussion}

\subsection{Analysis of Phase One}

Figure 6 depicts how light shelf height affects the daylighting performance of light shelves regarding the uniformity and distribution of WPI levels at distances of $1 \mathrm{~m}$ and $7 \mathrm{~m}$ from the window of the office where testing was performed. Remarkably, WPI levels in front of the window exceed 750 lux for all height levels used in this study and all design days. Additionally, the WPI levels of LS2H2 and LS3H3 are less compared to LS1H1, especially at midday. The illuminance level at the back daylit area was less than half of the illuminance level of the front area. However, the WPI levels were almost within the recommended range. Consequently, the uniformity index of LS1H1 is less than 0.5 at the winter solstice and during the mid-season due to the low angle of incidence of the Sun's path, as depicted in Figure 2. This leads to a higher contrast between daylight distribution near the window and the back surface. The LS2H2 and LS3H3 configurations achieved the uniformity index value at all times except during the winter solstice. It is worth mentioning that the width of the external light shelves influenced the integrated solar panel in terms of power generation during the last phase. However, its drawback is that there may be infringement concerns regarding the prospect right and damage due to wind pressure [6]. Therefore, the LS2H2 configuration was chosen for the width of the light shelf and 2/3rd of the window height, which is in line with previous studies [31]. 

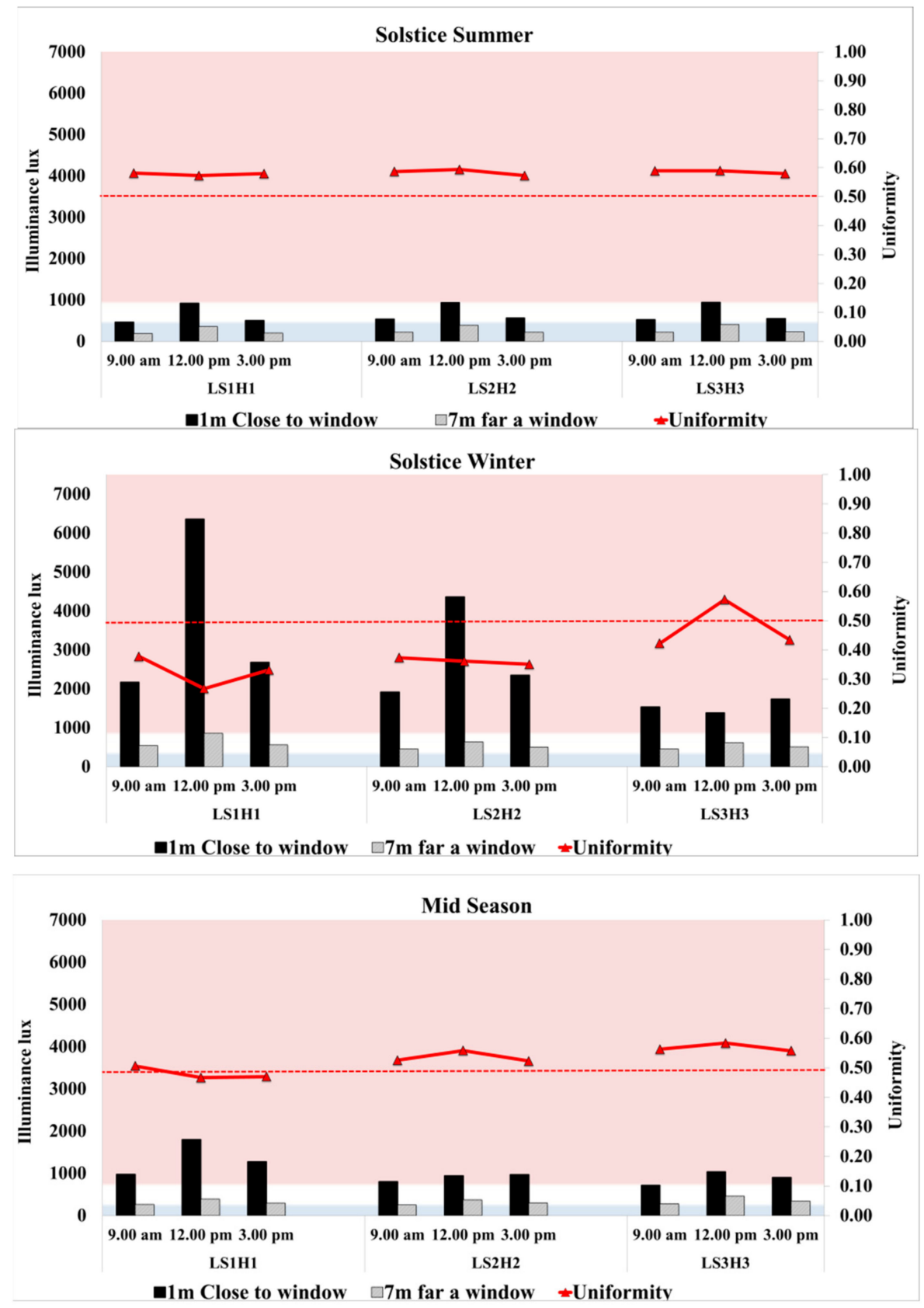

Figure 6. The effect of the position of internal and external light shelves at a distance of $1 \mathrm{~m}$ and $7 \mathrm{~m}$ from the window.

\subsection{Analysis of Phase Two}

Figure 7 depicts the introduction of the reflector material added at the top of the window compared to LS2H2. There is a remarkable increase of about $10 \%$ in WPI level distribution in the back daylit area. However, the WPI value pertaining to the front and back daylit area during the winter solstice is much higher than the recommended value, especially at midday. The uniformity index also witnessed improvement for all design days compared to the LS2H2 configuration (without a reflector), except for during the winter solstice. Thus, the use of a reflector at the top of the window, along with external and internal light shelves, is a useful daylight configuration for improving the WPI in the back space of the model. This result aligned with Zazzini et al.'s research [6]. Furthermore, uniformity is also enhanced in the said configuration; however, remarkable reflection is a concern when the Sun's path is low during the winter season. 


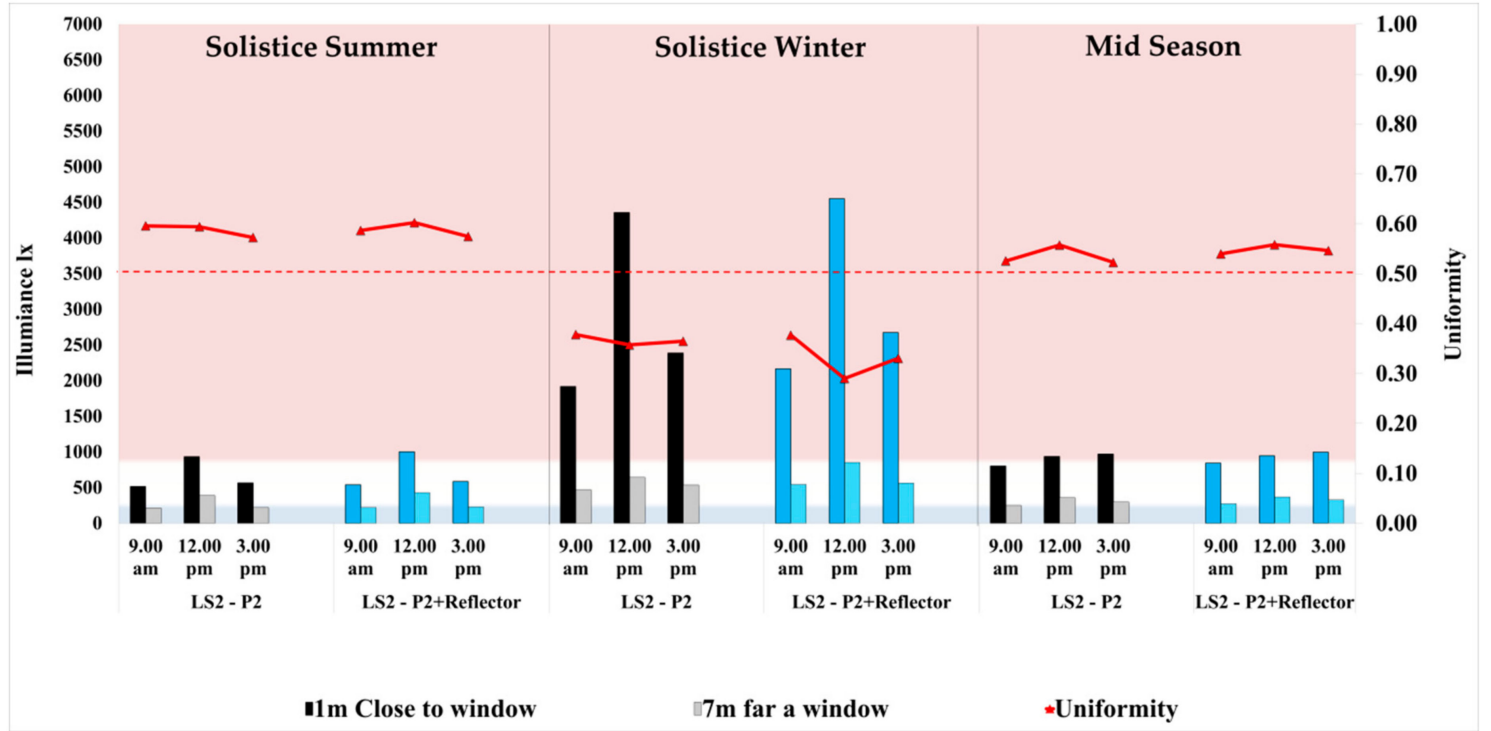

Figure 7. The performance of a reflector on the top of window combined with external and internal light shelves.

\subsection{Analysis of Phase Three}

Figure 8 depicts the distribution of indoor illuminance using three different internal curved LS angles $(10 \%, 15 \%$, and $25 \%)$ compared to horizontal LS on all design days. The results revealed that the use of an internal curved LS with $10^{\circ}$ tilt angle recorded the highest value of WPI and uniformity index at a distance of $7 \mathrm{~m}$ from the window. The back daylit area saw an increase of up to $5-11 \%$ on these parameters during the summer and winter solstices; however, the increase was less than $4 \%$ at the spring equinox. The uniformity index also saw an improvement for all the seasons. The WPI value at about a $4 \mathrm{~m}$ distance from the window (middle area) and the front area is within the recommended range, except at midday, where it is consistently higher than 750 lux. The LSC 3 configuration with $25^{\circ}$ tilt angle presents the least optimal case since the WPI increased for the front area but decreased for the back area, which results in less uniformity in daylight distribution. Thus, the optimal tilt angle of LS is $10^{\circ}$ (LSC1) for all seasons. In contrast, Heangwoo et al. [35] found that the optimal specifications for external curved light shelves are different depending on the season, but are effective at improving the indoor uniformity ratio compared to a flat light shelf during summer.

Overall, the observations from the optimized light shelf configurations after the three phases (height, reflector, curved internal light shelf) were compared with the reference model (without the light shelf). The proposed model illustrated a significant improvement considering the uniformity index on all design days, especially during midday. Furthermore, there was an increase of about $13-20 \%$ in the absolute WPI value concerning the back daylit area during the summer season for the entire day. At the same time, the absolute WPI value reduced for the middle $\left(63^{\circ}\right)$ and low $\left(39^{\circ}\right)$ sun path altitudes, as specified in Appendix B. 

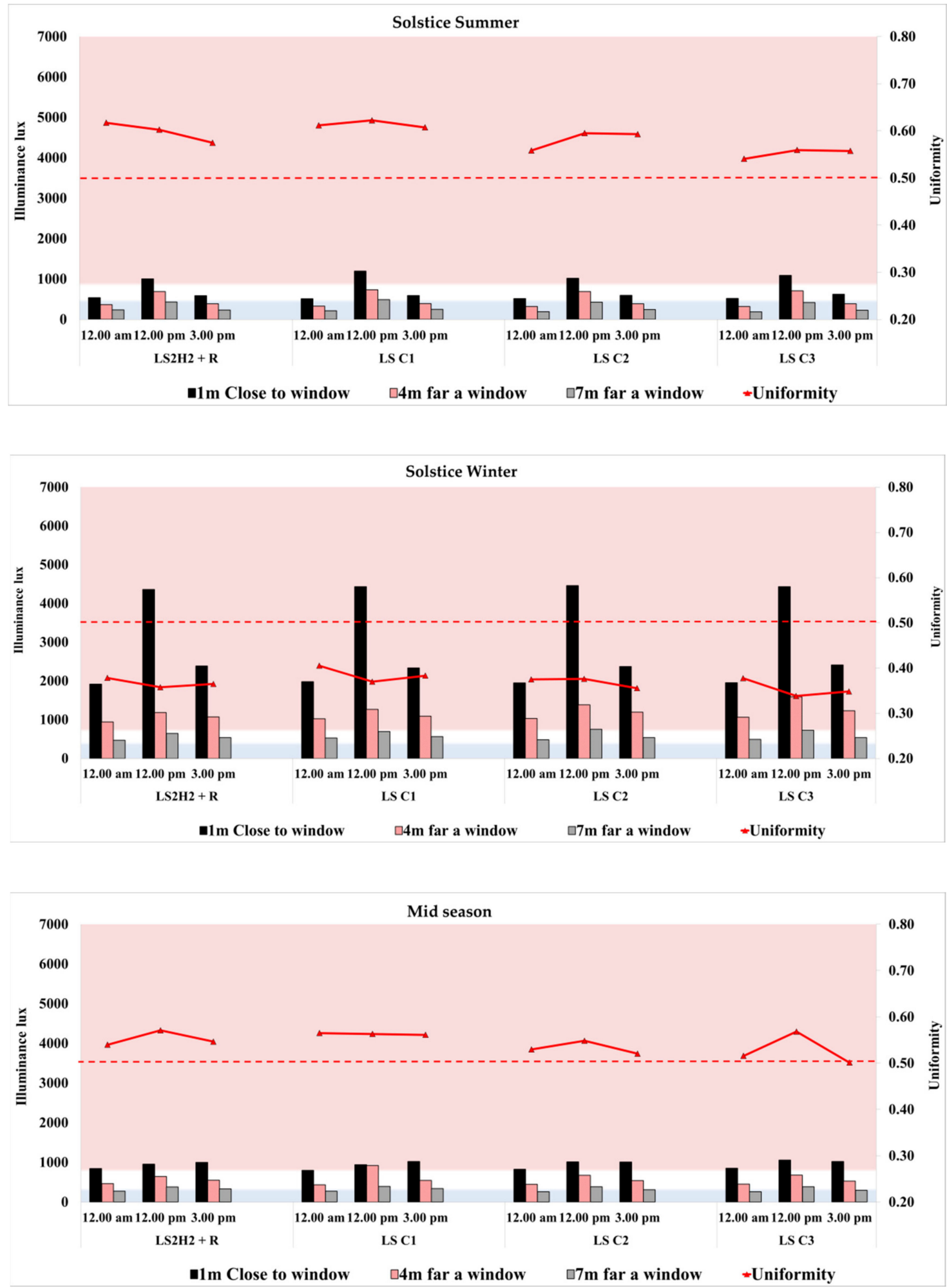

Figure 8. The performance of various curved light shelves in distance of $1 \mathrm{~m}, 4 \mathrm{~m}$ and $7 \mathrm{~m}$ from the window and Uniformity.

\subsection{Performance Evaluation of Light Shelf Photovoltaic Configurations (LSPV) (Phase Four)}

Tables 7-9 present the WPI distribution and uniformity index for the reference model and the many LSPV configurations corresponding to CIE clear sky within the design days. During the summer 
season, the WPI values and their averages concerning the reference model are higher than all LSPV configurations, especially during midday, as measured in the front area. It is also observed that in all cases, the uniformity index is higher than 0.5. Notably, the usage of LSPV leads to a noteworthy improvement in the WPI and uniformity index as compared to the reference model. The improvement in these parameters is better during midday, especially for configurations LSPV1 and LSPV2. In the case of the winter season, all WPI values are higher than 500 lux for all the configurations, except for the middle and back daylit area specific to the LSPV2 configuration. At the same time, the uniformity index improved for all the cases, but it was still less than 0.5. As for the mid-season results, the LSPV with a $30^{\circ}$ tilted angle witnessed an increase in WPI at midday, while the LSPV with a horizontal angle witnessed an increase during the evening as a result of the low sun position. The only configuration that had uniformity was LSPV2, unlike the reference model.

Table 7. The point in time illuminance of PV integration with light shelves and uniformity at solstice summer.

\begin{tabular}{ccccccccccc}
\hline Configurations & Solstice Summer & L1 & L2 & L3 & L4 & L5 & L6 & L7 & Average & Uniformity \\
\hline \multirow{3}{*}{ Reference Model } & 9.00 a.m. & 441 & 432 & 363 & 292 & 236 & 196 & 177 & 305 & 0.58 \\
& 12.00 p.m. & 1016 & 972 & 795 & 628 & 501 & 415 & 376 & 672 & 0.56 \\
& 3.00 p.m. & 480 & 467 & 392 & 316 & 257 & 216 & 194 & 332 & 0.59 \\
\hline \multirow{2}{*}{ LSPV1 } & 9.00 a.m. & 352 & 333 & 278 & 229 & 190 & 162 & 148 & 242 & 0.61 \\
& 12.00 p.m. & 658 & 644 & 543 & 449 & 376 & 323 & 300 & 470 & 0.64 \\
& 3.00 p.m. & 427 & 408 & 351 & 299 & 259 & 230 & 215 & 313 & 0.69 \\
\hline \multirow{2}{*}{ LSPV2 } & 9.00 a.m. & 350 & 333 & 287 & 245 & 210 & 183 & 169 & 254 & 0.67 \\
& 12.00 p.m. & 577 & 558 & 478 & 401 & 336 & 289 & 267 & 415 & 0.64 \\
LSPV3 & 3.00 p.m. & 376 & 354 & 304 & 259 & 219 & 191 & 175 & 268 & 0.65 \\
\hline \multirow{3}{*}{ LSPV4 } & 9.00 a.m. & 380 & 362 & 303 & 248 & 205 & 175 & 159 & 262 & 0.61 \\
& 12.00 p.m. & 764 & 755 & 645 & 530 & 441 & 372 & 341 & 550 & 0.62 \\
& 3.00 p.m. & 426 & 404 & 399 & 278 & 230 & 197 & 180 & 302 & 0.60 \\
\hline \multirow{2}{*}{ LSPV5 } & 9.00 a.m. & 308 & 339 & 284 & 277 & 190 & 160 & 145 & 243 & 0.60 \\
& 12.00 p.m. & 700 & 686 & 587 & 485 & 401 & 340 & 308 & 501 & 0.61 \\
& 3.00 p.m. & 420 & 402 & 342 & 284 & 236 & 202 & 184 & 296 & 0.62 \\
\hline \multirow{2}{*}{ LSPV6 } & 9.00 a.m. & 472 & 454 & 385 & 320 & 265 & 226 & 205 & 332 & 0.62 \\
& 12.00 p.m. & 849 & 838 & 711 & 583 & 480 & 404 & 368 & 605 & 0.61 \\
& 3.00 p.m. & 562 & 537 & 460 & 385 & 323 & 279 & 254 & 400 & 0.64 \\
\hline & 9.00 a.m. & 431 & 410 & 342 & 277 & 225 & 189 & 170 & 292 & 0.58 \\
& 12.00 p.m. & 898 & 889 & 748 & 604 & 489 & 406 & 365 & 628 & 0.58 \\
& 3.00 p.m. & 532 & 512 & 439 & 369 & 314 & 272 & 248 & 384 & 0.65 \\
\hline & 9.00 a.m. & 502 & 481 & 405 & 337 & 268 & 225 & 203 & 346 & 0.59 \\
& 12.00 p.m. & 932 & 918 & 771 & 627 & 513 & 428 & 390 & 654 & 0.60 \\
& 3.00 p.m. & 565 & 546 & 466 & 385 & 321 & 276 & 260 & 403 & 0.65 \\
\hline & 9.00 a.m. & 517 & 496 & 419 & 442 & 280 & 235 & 211 & 371 & 0.57 \\
& 12.00 p.m. & 898 & 889 & 748 & 604 & 448 & 406 & 365 & 623 & 0.59 \\
& 3.00 p.m. & 507 & 488 & 406 & 323 & 260 & 216 & 191 & 342 & 0.56 \\
\hline
\end{tabular}


Table 8. The point in time illuminance of PV integration with light shelves and uniformity at solstice winter.

\begin{tabular}{ccccccccccc}
\hline Configurations & Solstice Winter & L1 & L2 & L3 & L4 & L5 & L6 & L7 & Average & Uniformity \\
\hline \multirow{3}{*}{ Reference Model } & 9.00 a.m. & 2434 & 3111 & 2501 & 1478 & 979 & 741 & 635 & 1697 & 0.37 \\
& 12.00 p.m. & 7242 & 11280 & 8307 & 2669 & 1880 & 1420 & 1185 & 4855 & 0.24 \\
& 3.00 p.m. & 2932 & 3881 & 3089 & 1816 & 1112 & 827 & 702 & 2051 & 0.34 \\
\hline \multirow{2}{*}{ LSPV1 } & 9.00 a.m. & 1804 & 2393 & 1571 & 914 & 638 & 515 & 450 & 1184 & 0.38 \\
& 12.00 p.m. & 4166 & 2970 & 1520 & 1093 & 850 & 691 & 606 & 1699 & 0.36 \\
& 3.00 p.m. & 2196 & 2197 & 1743 & 1002 & 670 & 543 & 474 & 1261 & 0.38 \\
\hline \multirow{3}{*}{ LSPV2 } & 9.00 a.m. & 1420 & 1927 & 1215 & 722 & 524 & 421 & 370 & 943 & 0.39 \\
& 12.00 p.m. & 1703 & 1239 & 939 & 740 & 557 & 475 & 322 & 854 & 0.38 \\
& 3.00 p.m. & 1635 & 2080 & 1250 & 763 & 546 & 435 & 380 & 1013 & 0.38 \\
\hline \multirow{2}{*}{ LSPV3 } & 9.00 a.m. & 1860 & 2235 & 1630 & 970 & 683 & 546 & 472 & 1199 & 0.39 \\
& 12.00 p.m. & 4225 & 2990 & 1560 & 1117 & 880 & 712 & 621 & 1729 & 0.36 \\
& 3.00 p.m. & 2228 & 2961 & 1498 & 1031 & 711 & 566 & 490 & 1355 & 0.36 \\
\hline \multirow{3}{*}{ LSPV4 } & 9.00 a.m. & 1550 & 2113 & 1336 & 784 & 551 & 445 & 391 & 1024 & 0.38 \\
& 12.00 p.m. & 2497 & 1705 & 1139 & 882 & 688 & 562 & 499 & 1139 & 0.44 \\
& 3.00 p.m. & 1854 & 2434 & 1458 & 870 & 620 & 485 & 420 & 1163 & 0.36 \\
\hline \multirow{3}{*}{ LSPV5 } & 9.00 a.m. & 1860 & 2446 & 1571 & 973 & 654 & 519 & 452 & 1211 & 0.37 \\
& 12.00 p.m. & 4274 & 3080 & 1636 & 1190 & 922 & 750 & 654 & 1787 & 0.37 \\
& 3.00 p.m. & 2308 & 3020 & 1817 & 1080 & 751 & 590 & 515 & 1440 & 0.36 \\
\hline \multirow{2}{*}{ LSPV6 } & 9.00 a.m. & 1728 & 2273 & 1518 & 881 & 630 & 500 & 432 & 1137 & 0.38 \\
& 12.00 p.m. & 3234 & 2170 & 1340 & 1006 & 793 & 641 & 563 & 1392 & 0.40 \\
& 3.00 p.m. & 2096 & 2695 & 1640 & 977 & 522 & 542 & 472 & 1278 & 0.37 \\
\hline \multirow{2}{*}{ LSPV7 } & 9.00 a.m. & 1943 & 2515 & 1686 & 994 & 707 & 560 & 484 & 1270 & 0.38 \\
& 12.00 p.m. & 4332 & 3110 & 1662 & 1170 & 908 & 737 & 644 & 1795 & 0.36 \\
& 3.00 p.m. & 2372 & 3085 & 1860 & 1127 & 800 & 633 & 551 & 1490 & 0.37 \\
\hline & 9.00 a.m. & 1874 & 2464 & 1622 & 956 & 675 & 538 & 462 & 1227 & 0.38 \\
& 12.00 p.m. & 3738 & 2585 & 1832 & 1067 & 825 & 670 & 586 & 1615 & 0.36 \\
& 3.00 p.m. & 1773 & 2910 & 1096 & 1052 & 713 & 567 & 492 & 1229 & 0.40 \\
\hline
\end{tabular}

Table 9. The point in time illuminance of PV integration with light shelves and uniformity at mid-season.

\begin{tabular}{|c|c|c|c|c|c|c|c|c|c|c|}
\hline Configurations & Equinox Spring & L1 & L2 & L3 & L4 & L5 & L6 & L7 & Average & Uniformity \\
\hline \multirow{3}{*}{ Reference Model } & 9.00 a.m. & 1208 & 856 & 645 & 502 & 394 & 324 & 284 & 602 & 0.47 \\
\hline & 12.00 p.m. & 6507 & 2525 & 1366 & 993 & 769 & 626 & 540 & 1904 & 0.28 \\
\hline & 3.00 p.m. & 2154 & 1173 & 814 & 615 & 481 & 394 & 348 & 854 & 0.41 \\
\hline \multirow{3}{*}{ LSPV1 } & 9.00 a.m. & 677 & 543 & 452 & 366 & 299 & 251 & 226 & 402 & 0.56 \\
\hline & 12.00 p.m. & 684 & 678 & 574 & 467 & 382 & 319 & 287 & 484 & 0.59 \\
\hline & 3.00 p.m. & 2196 & 2502 & 1743 & 1002 & 505 & 543 & 474 & 1281 & 0.37 \\
\hline \multirow{3}{*}{ LSPV2 } & 9.00 a.m. & 546 & 435 & 360 & 293 & 240 & 199 & 177 & 321 & 0.55 \\
\hline & 12.00 p.m. & 1703 & 1240 & 939 & 577 & 483 & 475 & 422 & 834 & 0.51 \\
\hline & 3.00 p.m. & 687 & 550 & 461 & 378 & 313 & 257 & 240 & 412 & 0.58 \\
\hline \multirow{3}{*}{ LSPV3 } & 9.00 a.m. & 704 & 580 & 478 & 386 & 312 & 259 & 231 & 421 & 0.55 \\
\hline & 12.00 p.m. & 799 & 789 & 676 & 551 & 447 & 374 & 336 & 567 & 0.59 \\
\hline & 3.00 p.m. & 2228 & 2960 & 1747 & 1031 & 711 & 566 & 490 & 1390 & 0.35 \\
\hline \multirow{3}{*}{ LSPV4 } & 9.00 a.m. & 652 & 534 & 441 & 361 & 295 & 252 & 228 & 395 & 0.58 \\
\hline & 12.00 p.m. & 2494 & 1700 & 1140 & 882 & 688 & 562 & 498 & 1138 & 0.44 \\
\hline & 3.00 p.m. & 825 & 653 & 554 & 454 & 373 & 315 & 282 & 494 & 0.57 \\
\hline \multirow{3}{*}{ LSPV5 } & 9.00 a.m. & 816 & 674 & 557 & 448 & 359 & 298 & 265 & 488 & 0.54 \\
\hline & 12.00 p.m. & 861 & 853 & 732 & 594 & 479 & 398 & 352 & 610 & 0.58 \\
\hline & 3.00 p.m. & 2308 & 3020 & 1817 & 1080 & 751 & 590 & 515 & 1440 & 0.36 \\
\hline \multirow{3}{*}{ LSPV6 } & 9.00 a.m. & 750 & 616 & 507 & 407 & 325 & 268 & 238 & 444 & 0.54 \\
\hline & 12.00 p.m. & 3234 & 2170 & 1037 & 1006 & 793 & 641 & 563 & 1349 & 0.42 \\
\hline & 3.00 p.m. & 897 & 741 & 600 & 482 & 388 & 322 & 288 & 531 & 0.54 \\
\hline \multirow{3}{*}{ LSPV7 } & 9.00 a.m. & 821 & 685 & 560 & 443 & 351 & 290 & 259 & 487 & 0.53 \\
\hline & 12.00 p.m. & 945 & 945 & 808 & 648 & 518 & 427 & 377 & 667 & 0.57 \\
\hline & 3.00 p.m. & 2322 & 3085 & 1860 & 1127 & 800 & 633 & 551 & 1483 & 0.37 \\
\hline \multirow{3}{*}{ LSPV8 } & 9.00 a.m. & 772 & 640 & 523 & 418 & 332 & 273 & 242 & 457 & 0.53 \\
\hline & 12.00 p.m. & 3738 & 2335 & 1460 & 1062 & 825 & 670 & 586 & 1525 & 0.38 \\
\hline & 3.00 p.m. & 933 & 757 & 619 & 493 & 382 & 318 & 280 & 540 & 0.52 \\
\hline
\end{tabular}


Figure 9 presents the mean values of the DA and UDI metrics for the deep office considering all SPV configurations. The analysis revealed that the reference model achieved $78.9 \%$ of the 300 lux mean value of DA, which is the highest percentage compared to the LSPV configurations, where LSPV with $100 \%$ and $75 \%$ coverage is less than $50 \%$. The annual distribution of DA for every grid point is depicted in Appendix C. In contrast, the UDI of LSPV (100-2000 lux) is higher at $90 \%$ compared to $83 \%$ for the reference model due to the high rate of visual discomfort compared to the LSPV configurations. The LSPV2 configuration almost eliminated visual discomfort (UDI > 2000).

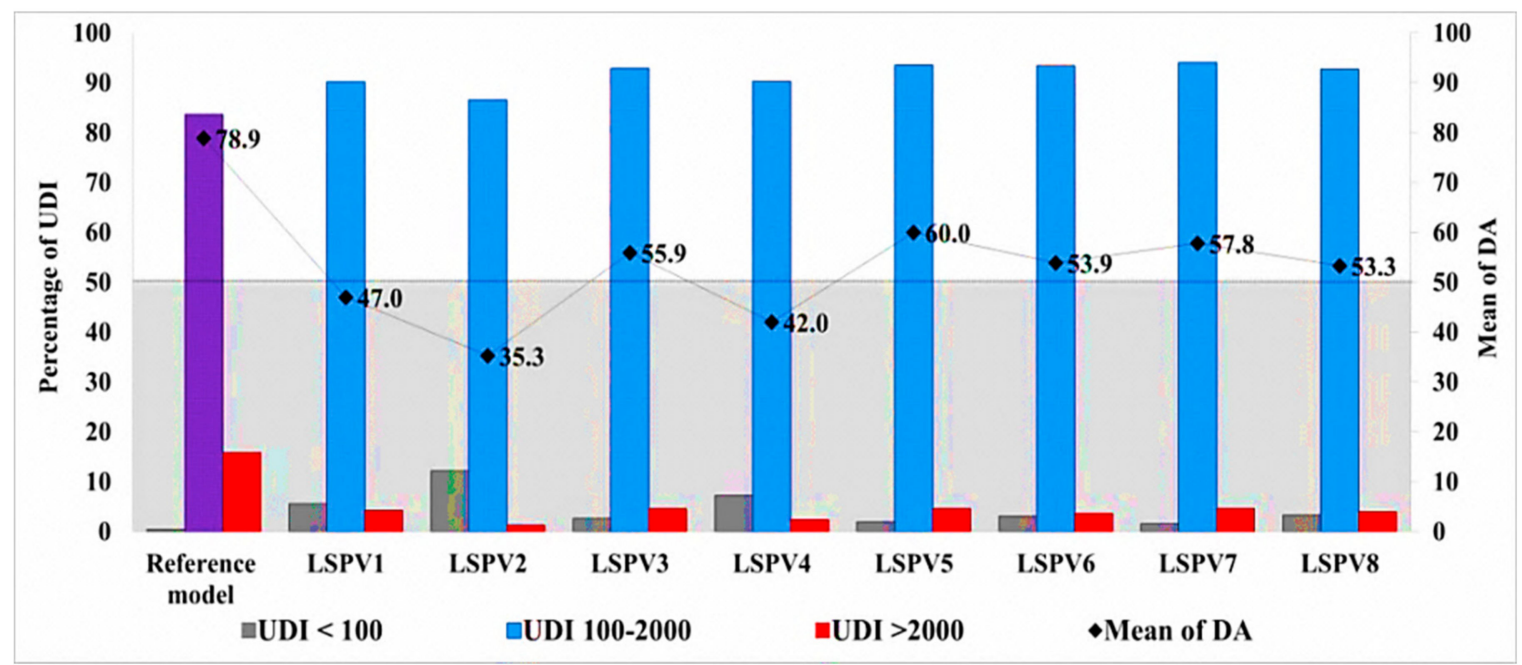

Figure 9. Annual climate-based analysis (UDI and mean of DA) of different configurations of light shelves integrated with photovoltaics.

Table 10 shows the magnitude of discomfort caused by glare for the reference model; optimal cases were determined using daylight glare probability (DGP) and a 3D contour map. The results revealed that a perceptible glare occurred only during the winter season when measured close to the window as per the reference model. This happened when the Sun was at its lowest and in direct view, specifically at noon. All LSPV configurations reduce the amount of DGP to an imperceptible glare condition. Eventually, configurations LSPV1 and LPSV2 with $100 \%$ coverage were considerably improved regarding visual comfort by reducing the mean values of DGP by at least nine degrees compared to the reference model. 
Table 10. Illuminance contour maps of the reference model and the optimum LSPV configurations under clear sky at solstice winter at (9.00 a.m., 12.00 p.m., 3.00 p.m.).

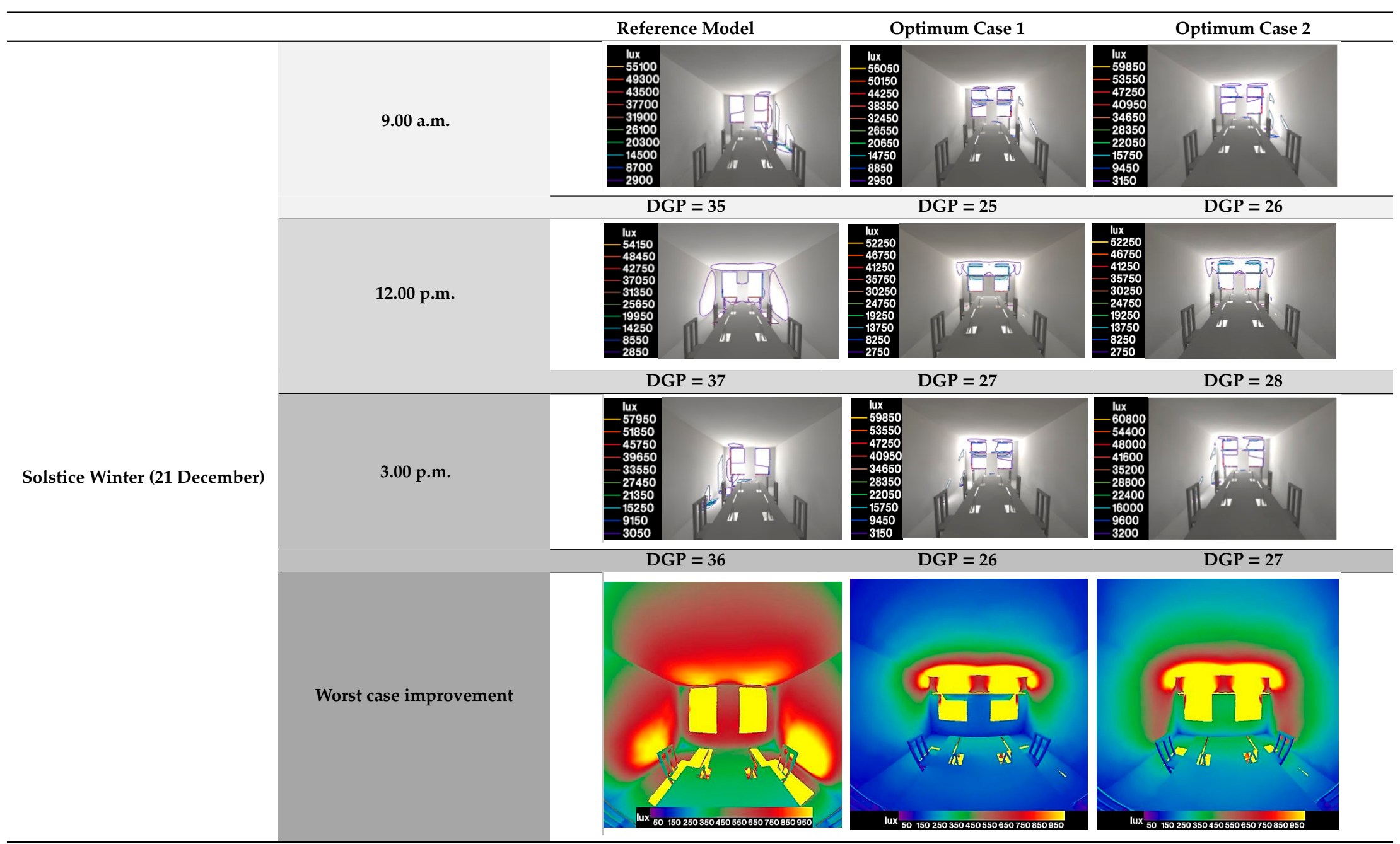




\subsection{Analysis of Artificial Lighting Energy Consumption}

Table 11 specifies the amount of energy production for the integrated LSPV and the total lighting energy consumption in each lighting control zone throughout the year pertaining to the climatic condition of Ha'il. For the analysis, it is assumed that lighting was switched on automatically after 8:00 a.m. and kept on until 5:00 p.m., with the dimming system set to 300 lux. The results show that the reference model (without LS) exhibited the lowest energy use compared to all LSPV configurations by a difference of only $20.6 \mathrm{kWh}$ per year, while the lowest lighting energy consumption of $49.7 \mathrm{kWh}$ was achieved for LSPV5, which is more than $50 \%$. Peak lighting energy demand for the deep office reached up to $102 \mathrm{kWh}$ for LSPV2.

Table 11. The yearly lighting energy consumption of various light shelf configurations compared to the base model.

\begin{tabular}{ccccc}
\hline $\begin{array}{c}\text { Configuration of } \\
\text { LS with PV }\end{array}$ & $\begin{array}{c}\text { Lighting Energy } \\
\text { Consumption (kWh) }\end{array}$ & $\begin{array}{c}\text { PV Energy } \\
\text { Production (kWh) }\end{array}$ & $\begin{array}{c}\text { Net Energy Saving (kWh) } \\
\text { Percentage of Energy Saved } \\
\text { with PV Light Shelves }\end{array}$ \\
\hline Reference model & 20.6 & 0 & -20.6 & $0 \%$ \\
LSPV1 & 71.8 & 626 & 554 & $89 \%$ \\
LSPV2 & 102.9 & 686 & 583 & $85 \%$ \\
LSPV3 & 50.3 & 469 & 419 & $89 \%$ \\
LSPV4 & 93.8 & 514 & 263 & $82 \%$ \\
LSPV5 & 49.7 & 313 & 289 & $84 \%$ \\
LSPV6 & 53.6 & 343 & 103 & $66 \%$ \\
LSPV7 & 53.1 & 156 & 108 & $63 \%$ \\
LSPV8 & 63.1 & 171 & & \\
\hline
\end{tabular}

On the other hand, the energy output due to PV use was much higher than the lighting energy consumption. PV energy output ranged between $107 \mathrm{kWh}$ for LSPV7 to $686 \mathrm{kWh}$ for LSPV2. Consequently, the annual lighting-specific energy savings were calculated for two tilt angles (horizontal and $30^{\circ}$ ) and four PV coverages. The net savings were computed relative to the energy output of PV and lighting energy demands. In all the cases, the results indicated a reduction of at least $63 \%$ and, in some cases, up to $89 \%$. Considering these observations, a light shelf using a solar module is advantageous concerning energy savings for lighting. Furthermore, the energy production can also compensate for a considerable fraction of other domestic energy needs, such as that required for cooling.

\section{Conclusions}

This study focused on the application of using integrated photovoltaic solar panels in light shelves to decrease the lighting energy requirement for office buildings and proposed a prototype of a modular unit composed of a light shelf combined with photovoltaic technology (LSPV) for deep office buildings in hot desert-like climatic conditions. In order to optimize the daylighting performance, three phases were carried out before the PV was attached to the LS to determine the appropriate height, reflector characteristics, and curved internal LS. The key findings of this study are specified below:

- The optimal height for a flat LS for enhancing WPI and the uniformity index determined in this study is $1.3 \mathrm{~m}$ above the floor with widths of $1.1 \mathrm{~m}$ and $0.7 \mathrm{~m}$ for the external and internal LS respectively, Configuration LS3H3 is challenging to use in high rise buildings.

- The use of a reflector with constant width of $30 \mathrm{~cm}$ at the top of the window, combined with external and internal LS configurations, is considered a good daylight strategy to improve the WPI in the back area of the model by $10 \%$.

- The optimal specification for a flat external LS, combined with a curved internal LS, for improving daylighting distribution was found to be $10^{\circ}$, which increased the back daylit area by up to $5-11 \%$ at the summer and winter solstices, and less than $4 \%$ at the spring equinox.

- All LS configurations are observed to provide less daylight in the back daylit area compared to the reference model; however, there is uniformity of illumination. 
- The integration of LSPV with a conversion efficiency of only $10 \%$ can completely compensate for the lighting-specific energy consumption in all LSPV configurations. At the same time, these configurations eliminate the discomfort caused due to glare, especially during the winter season. Also, LSPV1 with a flat and $30^{\circ}$ tilt angle with $100 \%$ coverage shows a higher uniformity of illumination compared to a light shelf without a solar module.

- The optimal modular units of the LSPV that can achieve significantly greater savings and uniformity index within the office perimeter, close to the windows and the middle, along with the back area, are LSPV1 and LSPV2, as specified in Appendix D.

The focus of this study is limited to the energy required for lighting and daylight distribution for visual comfort. However, further studies are needed to evaluate the effect of the wall-to-window ratio (WWR) and other types of photovoltaic materials, specifically with respect to conversion efficiency, the effects of transparency on energy saving, and glare prevention. The effects of combined internal and external light shelves on window view also need further investigation. Moreover, the potential integration of LSPV had a significant impact on providing uniform daylight and preventing $\mathrm{CO}_{2}$ emissions. Finally, such structures can be conveniently installed in buildings during renovation.

Author Contributions: Conceptualization, A.M. and A.G.; methodology, A.M.; software, A.M..; validation, A.M.; formal analysis, A.M.; investigation, A.M.; resources, A.M.; data curation, A.M. and A.G.; writing-original draft preparation, A.M.; writing-review and editing, A.G.; visualization, A.G.; supervision, A.G.; project administration, A.G.; funding acquisition, A.G. All authors have read and agreed to the published version of the manuscript.

Funding: This research received no external funding.

Acknowledgments: I would like to thanks Mesloub said for his support to complete this project. Also the authors would thank the editor, the managing editor, the academic editor, and three anonymous reviewers for their helpful comments which improved earlier versions of manuscript.

Conflicts of Interest: The authors declare no conflict of interest.

\section{Nomenclature}

$\begin{array}{ll}\text { LSPV } & \text { Light shelf photovoltaics } \\ \text { ILS } & \text { Internal light shelf } \\ \text { ELS } & \text { External light shelf } \\ \text { STPV } & \text { Semi-transparent photovoltaics } \\ \text { ISO } & \text { International Organization for Standardization } \\ \text { CEI } & \text { Commission International d'Eclairage } \\ \text { WPI } & \text { Work plane illuminance } \\ \text { TMY } & \text { Meteonorm metrological database } \\ \text { LS1H1 } & \text { Light shelf height } \\ \text { LSC } & \text { Light shelf curved } \\ \text { LS2H2 }+ \text { R } & \text { Light shelf height }+ \text { reflector } \\ \text { VLT } & \text { Visible light transmittance } \\ \text { WWR } & \text { Window-to-wall ratio } \\ \text { UI } & \text { Uniformity index } \\ \text { UDI } & \text { Useful daylight illuminance } \\ \text { DA } & \text { Daylight autonomy } \\ \text { DGP } & \text { Daylight glare index } \\ \mathrm{h}_{\text {clerestory }} & \text { Height of clerestory } \\ \mathrm{d}_{\text {int light shelf }} & \text { Depth of internal light shelf } \\ \mathrm{d}_{\text {ext light shelf }} & \text { Depth of external light shelf } \\ & \end{array}$


Appendix A

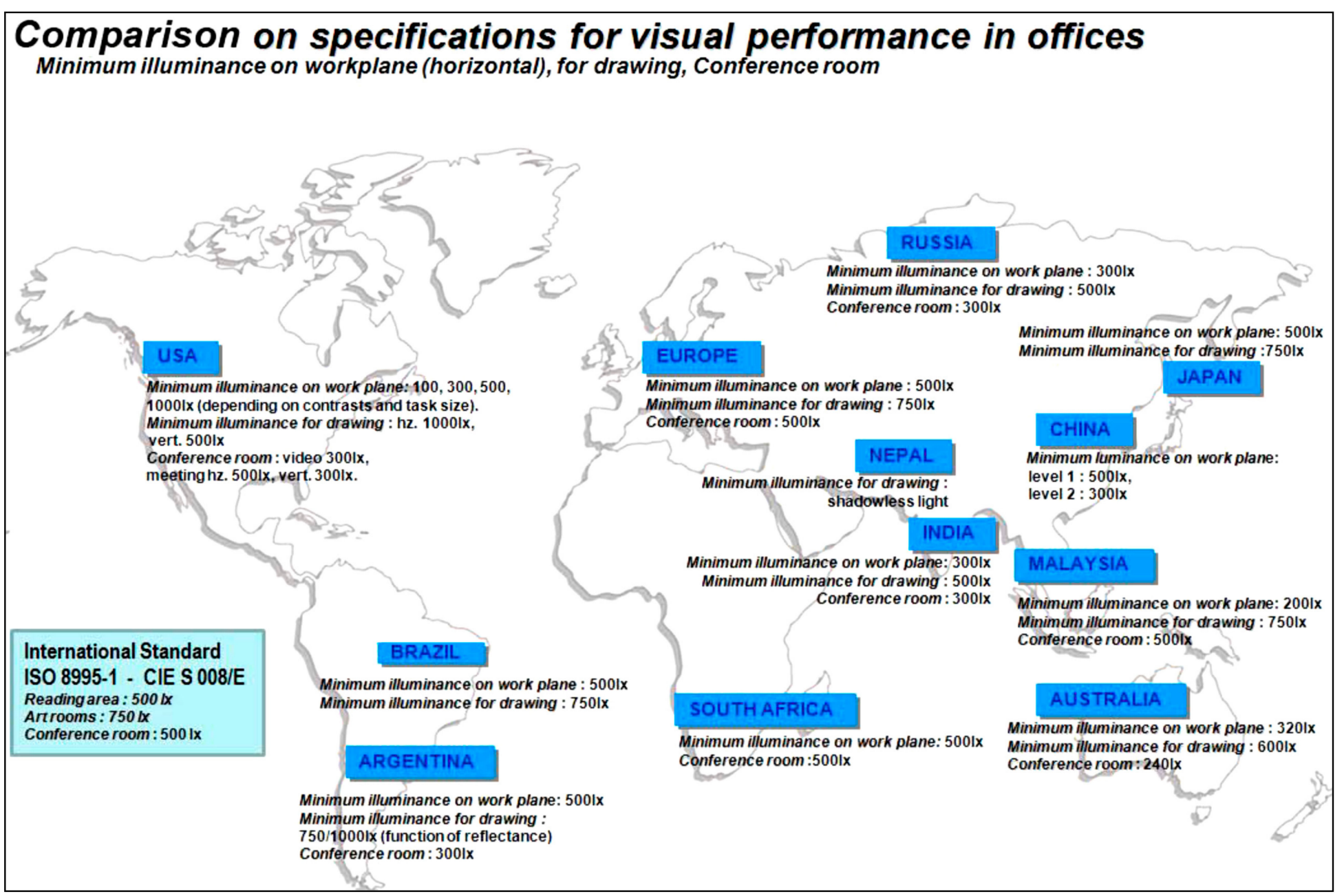

(A)

Figure A1. Cont. 


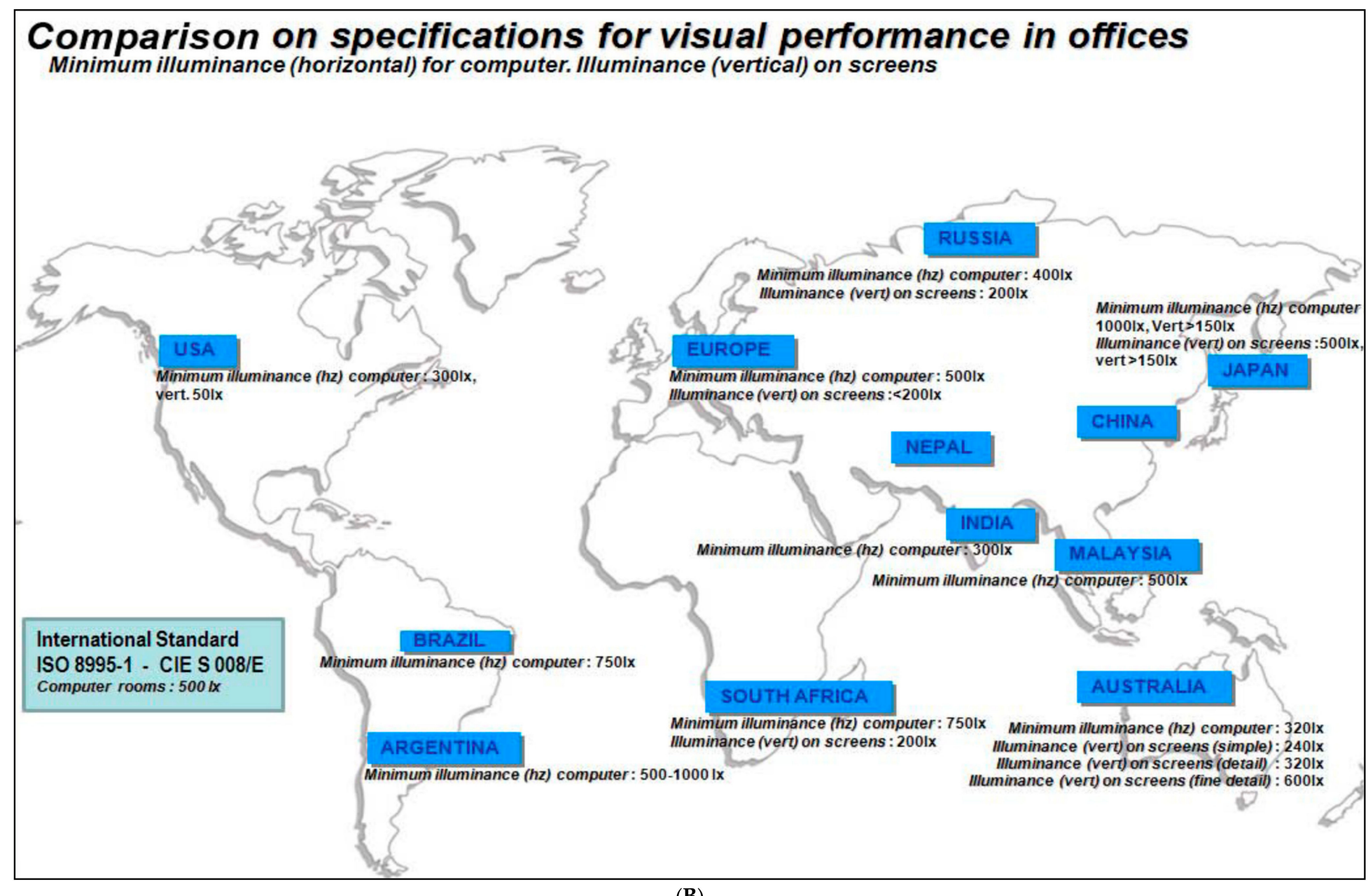

(B)

Figure A1. The minimum illuminance level based on International Standard ISO 8995-1:2002 (CIE 2001/ISO 2002) for visual performance in office (A) WPI horizontal for a drawing task (B) for a computer task. 


\section{Appendix B}

Table A1. The distribution of absolute work plan illuminance (WPI) and uniformity of the reference model compared to the optimized internal and external light shelves without integrating a solar module in (a) solstice summer, (b) equinox spring, and (c) solstice winter.

\begin{tabular}{|c|c|c|c|c|c|c|c|c|c|c|}
\hline \multicolumn{11}{|c|}{ (a) } \\
\hline Configurations & Solstice Summer & L1 & L2 & L3 & L4 & L5 & L6 & L7 & Average & Uniformity \\
\hline \multirow{3}{*}{ Reference Model } & 9.00 a.m. & 441 & 432 & 363 & 292 & 236 & 196 & 177 & 305 & 0.58 \\
\hline & 12.00 p.m. & 1016 & 972 & 795 & 628 & 501 & 415 & 376 & 672 & 0.56 \\
\hline & 3.00 p.m. & 480 & 467 & 392 & 316 & 257 & 216 & 194 & 332 & 0.59 \\
\hline \multirow{3}{*}{ LS C1 } & 9.00 a.m. & 511 & 490 & 409 & 332 & 270 & 226 & 214 & 350 & 0.61 \\
\hline & 12.00 p.m. & 1196 & 1039 & 893 & 736 & 612 & 524 & 488 & 784 & 0.62 \\
\hline & 3.00 p.m. & 593 & 572 & 483 & 393 & 320 & 269 & 250 & 411 & 0.61 \\
\hline \multicolumn{11}{|c|}{ (b) } \\
\hline Configurations & Equinox Spring & L1 & L2 & L3 & L4 & L5 & L6 & L7 & Average & Uniformity \\
\hline \multirow{3}{*}{ Reference Model } & 9.00 a.m. & 1208 & 856 & 645 & 502 & 394 & 324 & 284 & 602 & 0.47 \\
\hline & 12.00 p.m. & 6507 & 2525 & 1366 & 993 & 769 & 626 & 540 & 1904 & 0.28 \\
\hline & 3.00 p.m. & 2154 & 1173 & 814 & 615 & 481 & 394 & 348 & 854 & 0.41 \\
\hline \multirow{3}{*}{ LS C1 } & 9.00 a.m. & 797 & 715 & 546 & 436 & 347 & 286 & 275 & 486 & 0.56 \\
\hline & 12.00 p.m. & 943 & 935 & 791 & 923 & 494 & 402 & 393 & 697 & 0.56 \\
\hline & 3.00 p.m. & 1023 & 841 & 690 & 550 & 437 & 362 & 340 & 606 & 0.56 \\
\hline \multicolumn{11}{|c|}{ (c) } \\
\hline Configurations & Solstice Winter & L1 & L2 & L3 & L4 & L5 & L6 & L7 & Average & Uniformity \\
\hline \multirow{3}{*}{ Reference Model } & 9.00 a.m. & 2434 & 3111 & 2501 & 1478 & 979 & 741 & 635 & 1697 & 0.37 \\
\hline & 12.00 p.m. & 7242 & 11,280 & 8307 & 2669 & 1880 & 1420 & 1185 & 4855 & 0.24 \\
\hline & 3.00 p.m. & 2932 & 3881 & 3089 & 1816 & 1112 & 827 & 702 & 2051 & 0.34 \\
\hline \multirow{3}{*}{ LS C1 } & 9.00 a.m. & 1984 & 2569 & 1747 & 1023 & 731 & 586 & 531 & 1310 & 0.41 \\
\hline & 12.00 p.m. & 4432 & 3210 & 1760 & 1267 & 985 & 801 & 695 & 1878 & 0.37 \\
\hline & 3.00 p.m. & 2338 & 3066 & 1866 & 1091 & 769 & 610 & 564 & 1472 & 0.38 \\
\hline
\end{tabular}

\section{Appendix C}

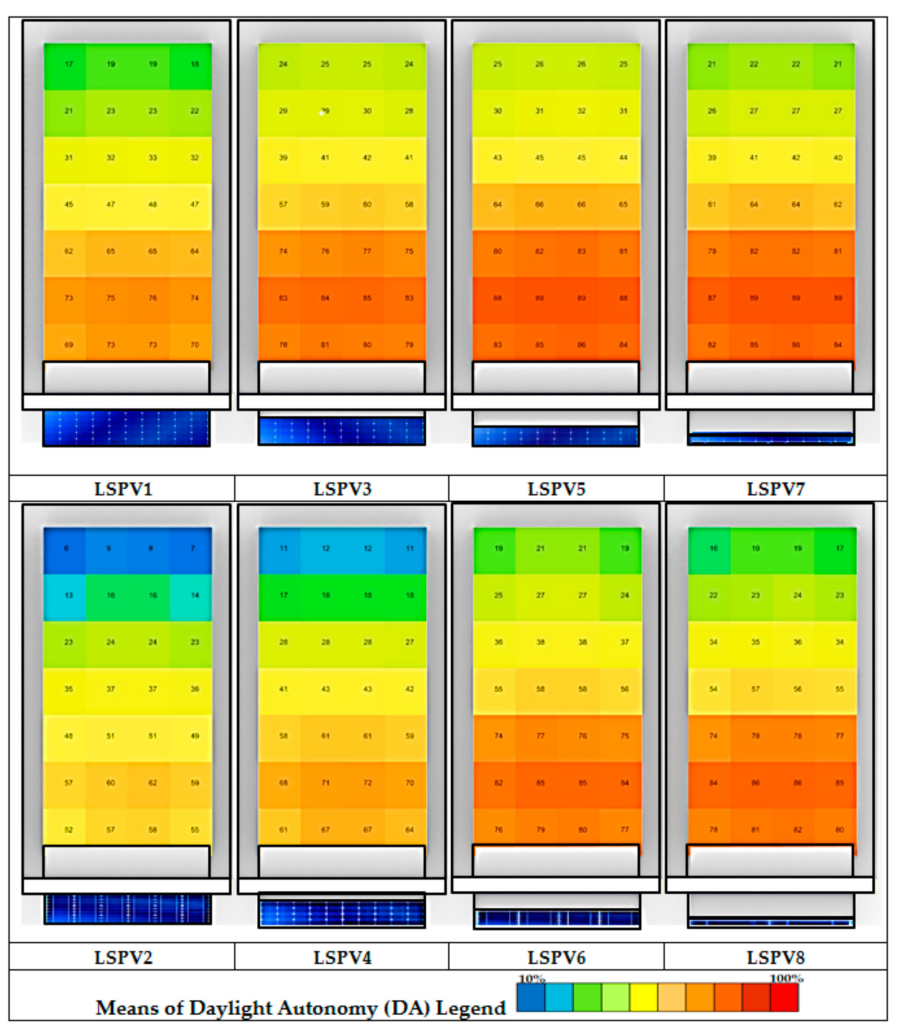

Figure A2. Daylight autonomy (DA) distribution of different LSPV configurations in each row. 


\section{Appendix D}
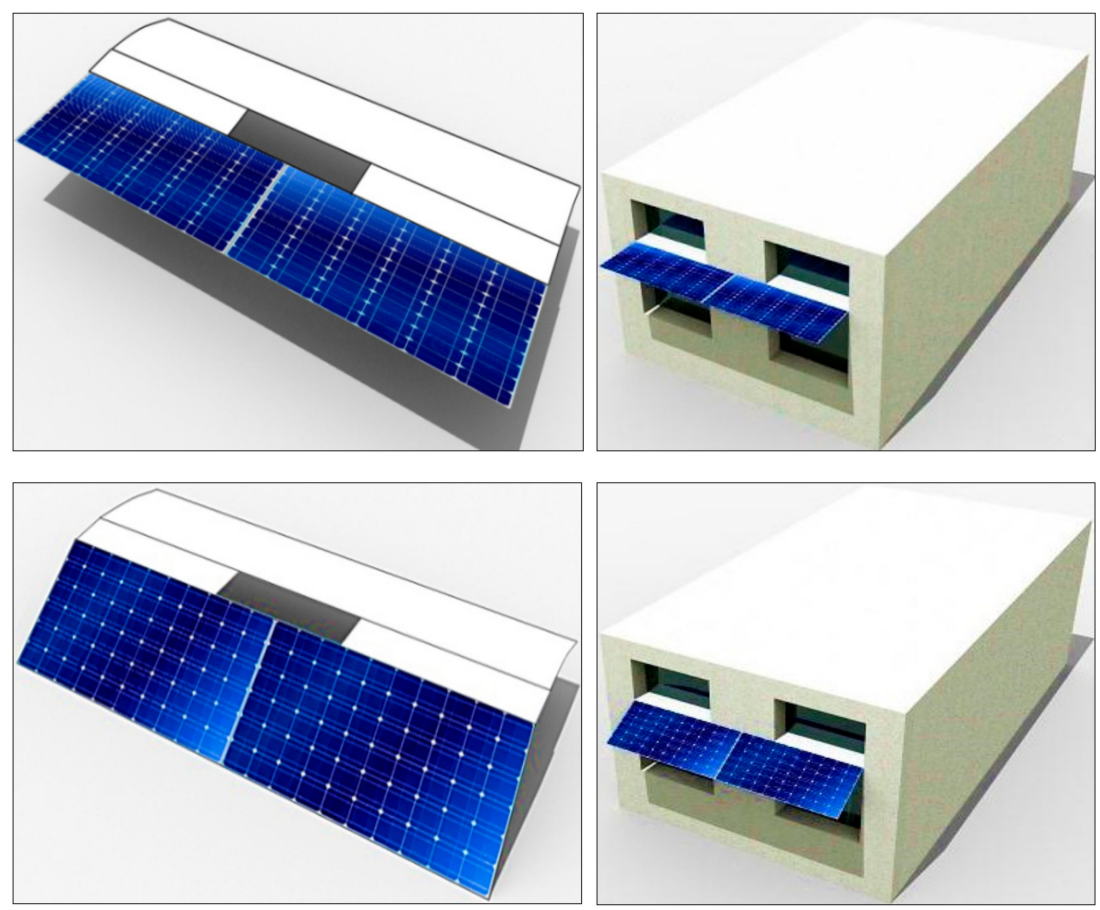

Figure A3. The optimum LSPV configuration design.

\section{References}

1. Saudi Vision 2030. Available online: https://vision2030.gov.sa/en/node/6 (accessed on 5 November 2020).

2. Qahtan, A.M.; Ebrahim, D.A.; Ahmed, H.M. Energy-saving potential of daylighting in the Atria of Colleges in Najran University, Saudi Arabia. Int. J. Built Environ. Sustain. 2020, 7, 47-55. [CrossRef]

3. Zell, E.; Gasim, S.; Wilcox, S.; Katamoura, S.; Stoffel, T.; Shibli, H.; Engel-Cox, J.; Al Subie, M. Assessment of solar radiation resources in Saudi Arabia. Sol. Energy 2015, 119, 422-438. [CrossRef]

4. Efficiency, S.E. Saudi Energy Efficiency Program; Governmental and Commercial Sector: Riyadh, Saudi Arabia, 2018.

5. Lim, Y.W.; Heng, C. Dynamic internal light shelf for tropical daylighting in high-rise office buildings. Build. Environ. 2016, 106, 155-166. [CrossRef]

6. Zazzini, P.; Romano, A.; di Lorenzo, A.; Portaluri, V.; di Crescenzo, A. Experimental analysis of the performance of light shelves in different geometrical configurations through the scale model approach. J. Daylighting 2020, 7, 37-56. [CrossRef]

7. Kontadakis, A.; Tsangrassoulis, A.; Doulos, L.; Zerefos, S. A review of light shelf designs for daylit environments. Sustainability 2018, 10, 71. [CrossRef]

8. Mesloub, A.; Albaqawy, G.A.; Kandar, M.Z. The OPTIMUM performance of Building Integrated Photovoltaic (BIPV) windows under a semi-arid climate in algerian office buildings. Sustainability 2020, 12, 1654. [CrossRef]

9. Gutiérrez, R.U.; Du, J.; Ferreira, N.; Ferrero, A.; Sharples, S. Daylight control and performance in office buildings using a novel ceramic louvre system. Build. Environ. 2019, 151, 54-74. [CrossRef]

10. Heng, C.; Lim, Y.W.; Ossen, D.R. Horizontal light pipe transporter for deep plan high-rise office daylighting in tropical climate. Build. Environ. 2020, 171, 106645. [CrossRef]

11. Freewan, A.A. Maximizing the lightshelf performance by interaction between lightshelf geometries and a curved ceiling. Energy Convers. Manag. 2010, 51, 1600-1604. [CrossRef]

12. Chieli, G.; Nelli, L.C. Photovoltaic and thermal solar concentrator integrated into a dynamic shading device. In Sustainable Building for a Cleaner Environment; Springer: Berlin, Germany, 2019; pp. 335-345.

13. Lee, H. Performance evaluation of a light shelf with a solar module based on the solar module attachment area. Build. Environ. 2019, 159, 106161. [CrossRef]

14. Raphael, B. Active control of daylighting features in buildings. Comput. Aided Civ. Infrastruct. Eng. 2011, 26, 393-405. [CrossRef] 
15. Meresi, A. Evaluating daylight performance of light shelves combined with external blinds in south-facing classrooms in Athens, Greece. Energy Build. 2016, 116, 190-205. [CrossRef]

16. Lee, H.; Jang, H.I.; Seo, J. A preliminary study on the performance of an awning system with a built-in light shelf. Build. Environ. 2018, 131, 255-263. [CrossRef]

17. Hwang, T.; Kim, J.T.; Chung, Y. Power performance of photovoltaic-integrated lightshelf systems. Indoor Built Environ. 2014, 23, 180-188. [CrossRef]

18. Berardi, U.; Anaraki, H.K. Analysis of the impacts of light shelves on the useful daylight illuminance in office buildings in Toronto. Energy Procedia 2015, 78, 1793-1798. [CrossRef]

19. Moazzeni, M.H.; Ghiabaklou, Z. Investigating the influence of light shelf geometry parameters on daylight performance and visual comfort, a case study of educational space in Tehran, Iran. Buildings 2016, 6, 26. [CrossRef]

20. Kim, K.; Lee, H.; Jang, H.; Park, C.; Choi, C. Energy-saving performance of light shelves under the application of user-awareness technology and light-dimming control. Sustain. Cities Soc. 2019, 44, 582-596. [CrossRef]

21. Lee, H.; Park, S.; Seo, J. Development and performance evaluation of light shelves using width-adjustable reflectors. Adv. Civ. Eng. 2018, 2018, 2028065. [CrossRef]

22. Bahdad, A.A.S.; Fadzil, S.F.S.; Taib, N. Optimization of daylight performance based on controllable light-shelf parameters using genetic algorithms in the tropical climate of malaysia. J. Daylighting 2020, 7, 122-136. [CrossRef]

23. Lee, H.; Seo, J. Performance evaluation of external light shelves by applying a prism sheet. Energies 2020, 13, 4618. [CrossRef]

24. International standard organization(ISO). Lighting of Indoor Work Places; ISO: Geneva, Switzerland, 2002.

25. DiLaura, D.L. Illuminating Engineering Societythe Lighting HandbookTenth Edition Reference and Application. 2011. Available online: http://ndl.ethernet.edu.et/handle/123456789/23109 (accessed on 9 November 2020).

26. JISZ9110. Recommended Levels of Illumination; Japanese Industrial Standards Committee: Tokyo, Japan, 2010.

27. De Normalisation, C.E. EN 12464-1: Light and Lighting-Lighting of Work Places, Part 1: Indoor Work Places; Comité Européen de Normalisation: Bern, Switzerland, 2002.

28. Bellia, L.; Pedace, A.; Fragliasso, F. Dynamic daylight simulations: Impact of weather file's choice. Sol. Energy 2015, 117, 224-235. [CrossRef]

29. Remund, J.; Müller, S.; Kunz, S.; Huguenin-Landl, B.; Studer, C.; Klauser, D.; Schilter, C.; Lehnherr, R. Meteonorm global meteorological database. In Hanbook I/II; Meteotest: Bern, Switzerland, 2013.

30. Berardi, U.; Anaraki, H.K. The benefits of light shelves over the daylight illuminance in office buildings in Toronto. Indoor Built Environ. 2018, 27, 244-262. [CrossRef]

31. Joarder, M.; Rahman, A.; Ahmed, Z.N.; Price, A.; Mourshed, M. A Simulation Assessment of the Height of Light Shelves to Enhance Daylighting Quality in Tropical Office Buildings under Overcast Sky Conditions in Dhaka, Bangladesh; International Building Performance Simulation Association: Glasgow, UK, 2009.

32. Hu, J.; Du, J.; Place, W. The assessment of advanced daylighting systems in multi-story office buildings using a dynamic method. In Proceedings of the World Renewable Energy Congress-Sweden, Linköping, Sweden, 8-13 May 2011; pp. 1867-1874.

33. Kensek, K.; Suk, J.Y. Daylight factor (overcast sky) versus daylight availability (clear sky) in computer-based daylighting simulations. J. Creat. Sustain. Archit. Built Environ. 2011, 1, 3-14.

34. Abdelhakim, M.; Lim, Y.W.; Kandar, M.Z. Optimum glazing configurations for visual performance in algerian classrooms under mediterranean climate. J. Daylighting 2019, 6, 11-22. [CrossRef]

35. Lee, H.; Seo, J.; Choi, C.H. Preliminary study on the performance evaluation of a light shelf based on reflector curvature. Energies 2019, 12, 4295. [CrossRef]

Publisher's Note: MDPI stays neutral with regard to jurisdictional claims in published maps and institutional affiliations. 